\title{
Does Federal Student Aid Raise Tuition? New Evidence on For-Profit Colleges
}

\section{Citation}

Cellini, Stephanie Riegg, and Claudia Goldin. 2014. “ Does Federal Student Aid Raise Tuition? New Evidence on For-Profit Colleges." American Economic Journal: Economic Policy 6 (4) (November): 174-206. doi:10.1257/pol.6.4.174.

\section{Published Version}

doi:10.1257/pol.6.4.174

\section{Permanent link}

http://nrs.harvard.edu/urn-3:HUL.InstRepos:27769883

\section{Terms of Use}

This article was downloaded from Harvard University's DASH repository, and is made available under the terms and conditions applicable to Open Access Policy Articles, as set forth at http:// nrs.harvard.edu/urn-3:HUL.InstRepos:dash.current.terms-of-use\#OAP

\section{Share Your Story}

The Harvard community has made this article openly available.

Please share how this access benefits you. Submit a story.

\section{Accessibility}


NBER WORKING PAPER SERIES

DOES FEDERAL STUDENT AID RAISE TUITION? NEW EVIDENCE ON FOR-PROFIT COLLEGES

Stephanie Riegg Cellini

Claudia Goldin

Working Paper 17827

http://www.nber.org/papers/w17827

\author{
NATIONAL BUREAU OF ECONOMIC RESEARCH \\ 1050 Massachusetts Avenue \\ Cambridge, MA 02138 \\ February 2012
}

We thank the many individuals at the state higher education and for-profit regulatory agencies of FL, MI, MO, TN and WI who helped us access the data for this project. We are grateful to Dana Hecht and Jason Poulos for excellent research assistance and to Sandy Baum, Latika Chaudhary, Jeffrey Groen, Larry Katz, John Karl Scholz, Judith Scott-Clayton, Lesley Turner, and three anonymous referees for helpful comments. Suggestions received from seminar participants at the NBER Education Program Meeting, AEFP, AEI, and the U.S. Department of Labor have made this a better paper. We are especially grateful to Lesley Turner for providing data on Pell Grant recipients by institution. The views expressed herein are those of the authors and do not necessarily reflect the views of the National Bureau of Economic Research.

At least one co-author has disclosed a financial relationship of potential relevance for this research. Further information is available online at http://www.nber.org/papers/w17827.ack

NBER working papers are circulated for discussion and comment purposes. They have not been peerreviewed or been subject to the review by the NBER Board of Directors that accompanies official NBER publications.

(C) 2012 by Stephanie Riegg Cellini and Claudia Goldin. All rights reserved. Short sections of text, not to exceed two paragraphs, may be quoted without explicit permission provided that full credit, including (C) notice, is given to the source. 
Does Federal Student Aid Raise Tuition? New Evidence on For-Profit Colleges

Stephanie Riegg Cellini and Claudia Goldin

NBER Working Paper No. 17827

February 2012, Revised April 2013

JEL No. I20,I22,I23

\begin{abstract}
$\underline{\text { ABSTRACT }}$
We use administrative data from five states to provide the first comprehensive estimates of the size of the for-profit higher education sector in the U.S. Our estimates include schools that are not currently eligible to participate in federal student aid programs under Title IV of the Higher Education Act and are therefore missed in official counts. We find that the number of for-profit institutions is double the official count and the number of students enrolled during the year is between one-quarter and one-third greater. Many for-profit institutions that are not Title IV eligible offer certificate (non-degree) programs that are similar, if not identical, to those given by institutions that are Title IV eligible. We find that the Title IV institutions charge tuition that is about 78 percent higher than that charged by comparable institutions whose students cannot apply for federal financial aid. The dollar value of the premium is about equal to the amount of grant aid and loan subsidy received by students in eligible institutions, lending some credence to a variant of the "Bennett hypothesis" that aid-eligible for-profit institutions capture a large part of the federal student aid subsidy.
\end{abstract}

\author{
Stephanie Riegg Cellini \\ Trachtenberg School of Public Policy \\ and Public Administration \\ George Washington University \\ 805 21st Street NW, \#601M \\ Washington, DC 20052 \\ and NBER \\ scellini@gwu.edu \\ Claudia Goldin \\ Department of Economics \\ Harvard University \\ Cambridge, MA 02138 \\ and NBER \\ cgoldin@harvard.edu
}


For-profit postsecondary education has expanded rapidly in recent years. The sector's “colleges" offer degrees and certificates in fields ranging from business and computer science to cosmetology and taxidermy. They serve millions of students every year, while generating substantial profits for investors.

In 2008/09 for-profits, as tracked by the U.S. Department of Education, produced 42 percent of vocational certificates, 18 percent of associate's degrees, 5 percent of bachelor's degrees, and 10 percent of master's degrees. Not only do for-profits account for a substantial fraction of each of these programs, they have also grown enormously in the past decade. The fall enrollment fraction accounted for by the for-profits increased from 4.3 percent in 2000 to 10.7 percent in 2009. ${ }^{1}$

There is a strong presumption that the size and growth of these institutions are, in part, due to the implicit subsidy received from federal student aid programs. Under Title IV of the Higher Education Act of 1965, the federal government provides grants and (subsidized and unsubsidized) loans to postsecondary students. For-profit post-secondary institutions account for about 23 percent of the total, or more than two times their enrollment share. ${ }^{2}$ Title IV eligible institutions (which we will term T4 institutions) may, and occasionally do, receive up to 90 percent of their revenue from federal aid programs.

Not all for-profit institutions participate in Title IV programs. As we will demonstrate, schools that are not Title IV eligible (hereafter termed non-Title IV or NT4 institutions) could very well outnumber T4 institutions in many states. Yet, most previous research on the for-profit sector has ignored them, as they are not captured in official U.S. Department of Education counts, offer mainly non-degree programs, and are far smaller than their Title IV counterparts. ${ }^{3}$

In this paper, we draw on administrative data from five states to provide the first estimates of the number of institutions, enrollments, and completions in NT4 institutions. We

\footnotetext{
${ }^{1}$ Data are from Deming, Goldin, and Katz (2012). These data are from the U.S. Department of Education and are only for institutions that are eligible for federal financial aid programs. "Fall enrollment" will understate the for-profits because many non-degree programs enroll students throughout the year.

${ }^{2}$ Totals for student aid are for 2007/08 and can be found in http://nces.edu.gov/fastfacts/disply.asp?id=31. The fraction accounted for by the for-profits is for 2008; see Deming, Goldin, and Katz (2012, figure 4). ${ }^{3}$ By non-degree programs we mean any that confer a diploma or certificate, not an Associate's (AA) or Bachelor's (BA) degree.
} 
also describe the types of programs offered by these institutions. We add these figures to those of T4 institutions, thereby providing the first comprehensive accounting of the size of the forprofit sector in its entirety.

More important, these data allow us to evaluate the so-called "Bennett hypothesis,” which argues that aid-eligible institutions capture part of federal aid by increasing tuition above the cost of education. ${ }^{4}$ By comparing the tuition charged by NT4 institutions to the tuition charged for similar programs in T4 institutions, we estimate the premium to Title IV eligibility for sub-baccalaureate programs. ${ }^{5}$

We estimate that NT4 institutions educate about 670,000 students each year—students who are missed in official U.S. Department of Education counts. After accounting for these students, we find that the entire for-profit sector provides education and training to 2.47 million students annually. The NT4 group accounts for about 50 percent of for-profit institutions and 27 percent of students. We also demonstrate that NT4 institutions offer programs in many of the same fields as T4 institutions. Further, our analysis suggests that rather than being new or ephemeral many NT4 institutions are long-lived, surviving and possibly thriving without access to Title IV funds and the imprimatur of the U.S. Department of Education.

In our tuition analysis, we find that for-profit T4 institutions charge much higher tuition than NT4 institutions across all states, samples, and specifications. To make a meaningful comparison, our estimates control for program length, enrollment, number of years of operation, and a rich set of program, county, and year fixed effects. To account for programs with some precision we use six-digit “Classification of Instructional Program” (CIP) codes as controls. We also compare programs in NT4 institutions that could meet particular Title IV eligibility standards with observationally equivalent programs in schools that actually are Title IV eligible.

Even with these rich controls we are sensitive to the possibility that there are quality

\footnotetext{
${ }^{4}$ See New York Times, February 18, 1987, opinion piece by William J. Bennett, then U.S. Secretary of Education. In it he famously said: "increases in financial aid in recent years have enabled colleges and universities blithely to raise their tuitions, confident that Federal loan subsidies would help cushion the increase.” http://www.nytimes.com/1987/02/18/opinion/our-greedy-colleges.html

${ }^{5}$ We should note at the outset that few NT4 institutions offer degree programs and almost none offers bachelor's and master's degrees. Therefore, we calculate tuition premia only for associate's degree and non-degree/certificate programs.
} 
differences between NT4 and T4 institutions that account for the tuition differences. We perform two estimations that address the quality issue in a somewhat different manner. One compares T4 and NT4 programs in the same six-digit CIP code (cosmetology) and includes occupational licensing exam pass rates by school to control for quality.

The other estimation uses school fixed effects. We demonstrate that within T4 schools, programs that are ineligible for federal student aid because they are too "short" have tuition amounts that are nearly identical to those for similar programs in institutions that are not Title IV eligible. But programs in a T4 that are longer and thus are Title IV eligible are considerably more expensive than similar "long” programs in the NT4 schools. In addition, the across-school difference between T4 and NT4 tuitions for these longer programs is about the same as the difference between the shorter and the longer programs within T4 institutions. These results strongly suggest that school quality is not the main driver of our tuition results between the T4 and NT4 schools.

Our preferred estimate of the tuition premium is about 58 log points (or 78 percent). Our findings suggest that $\mathrm{T} 4$ institutions raise gross tuition above the cost of education, as reflected in the tuition of the NT4 institutions. Further, the magnitude of the tuition premium for the cosmetology schools in our sample is roughly equal to average student grant awards and our estimate of the loan subsidy. We know from other analyses that many of the T4 institutions spend considerably on student recruitment and services and that these expenditures may account for part of their higher tuition. What the general equilibrium impact of Title IV is, and thus the incidence of the subsidy, must be reserved for future research although we return to these issues at the end.

This paper is the first (to our knowledge) to estimate tuition differences as a function of eligibility for federal student aid and the first to explore the Bennett Hypothesis using a sample of for-profit institutions. Previous studies of the Bennett hypothesis among public and non-profit institutions have found mixed results, as we discuss below. Further, recent regulations by the U.S. Department of Education proposed new tests of the "gainful employment" of for-profit graduates. Although the regulation is facing legal challenges, some analysts predict that the Title IV status of some, and possibly many, institutions will be revoked or suspended in the coming 
years, under gainful employment or a similar regulation. ${ }^{6}$ An understanding of the large number of NT4 institutions that operate without the support of federal student aid programs can provide an important lens through which the future of the for-profit sector can be viewed.

Section I provides background on Title IV and its role in for-profit postsecondary education. Section II describes our data. Section III discusses the characteristics of NT4 institutions and generates an estimate of the size of the whole for-profit sector. Section IV describes our empirical approach to estimating the Title IV tuition premium and Section V reports our results. Section VI concludes.

\section{Background: Title IV and For-Profit Higher Education}

Title IV of the Higher Education Act of 1965 allows institutions meeting certain criteria to be eligible to participate in federal student aid programs. Title IV programs come in three forms: grants, loans, and work-study. By far the largest Title IV grant program is the Pell Grant, which offers scholarships of up to \$5,500 (maximum in 2012) per year for low-income students in eligible institutions. Loan programs include subsidized (for students demonstrating financial need) and unsubsidized Stafford loans, Perkins loans, and PLUS loans for parents. During the 2007/08 academic year, more than \$125 billion in federal loans and grants were made to almost 14 million students. ${ }^{7}$ Almost two-thirds of all undergraduates receive some form of federal financial aid.

Institutions play a central role in determining a student’s financial aid award. Federal student aid awards are based on two main factors: Expected Family Contribution (EFC) and the Cost of Attendance (COA). Each student's EFC is determined by family income, assets, number of siblings, and other student-specific considerations reported on the Free Application for

\footnotetext{
${ }^{6}$ See Guryan and Thompson (2010), although their analysis was not based on the final regulations. A more recent exposition can be found in Deming, Goldin and Katz (2013). Although its legal future is uncertain at the time of this writing, the gainful employment regulation states that a program at a forprofit school leads to gainful employment if (1) at least 35 percent of the students in each cohort are in repayment of their federal loans or (2) the annual loan payment for a typical student is 12 percent or less of annual earnings or 30 percent or less of discretionary income. A program that fails both measures for three out of four fiscal years would lose Title IV eligibility.

${ }^{7}$ See http://nces.ed.gov/fastfacts/display.asp?id=31
} 
Federal Student Aid (FAFSA). ${ }^{8}$ The information is then furnished to each institution that a student is considering. The institution calculates its COA and weighs this against the EFC to determine the size and composition of the federal aid award. Several different factors may be considered in assessing the COA (e.g., cost of books and materials, part-time attendance, program length), but tuition is typically the most important element. All else equal, an institution with higher tuition will have a higher COA and the student in question will thereby qualify for more federal aid - whether grants or loans. This calculus undoubtedly creates an incentive for T4 institutions to raise tuition above the cost of education to capture a larger amount of aid, a point to which we return below.

To be Title IV eligible an institution must have existed for at least two years, have received accreditation from a U.S. Department of Education approved accrediting agency, and be licensed or authorized by the state in which it operates. A T4 institution must have at least one program that is full time (generally 900 clock hours), but some of its shorter programs can be approved for funding. Of importance to our analysis is that programs of 600 and more clock hours are generally eligible and those between 300 and below 600 have some eligibility. But those under 300 hours have no eligibility even if the school offering the program is Title IV eligible. ${ }^{9}$ For institutions that are already Title IV eligible maintenance of eligibility includes various requirements, such as not exceeding a maximum default rate on federal loans for students who have already completed or ended their programs. Further, institutions are not allowed to receive more than 90 percent of their revenue from Title IV loans and grants.

Not all postsecondary institutions can be, or choose to be, Title IV eligible. The restrictions just mentioned preclude participation in Title IV programs of some institutions. But there are many that do not participate in Title IV yet appear to qualify. As we show below, many of these institutions survive without Title IV. For example, in Michigan, we observe that NT4 institutions have been open, on average, for almost 11 years. Moreover, about 200 NT4

\footnotetext{
${ }^{8}$ On the complexity of the FAFSA form and the difficulty many students have in filling out student loan and grant applications, see Dynarski and Scott-Clayton (2008).

${ }^{9}$ See Skinner (2007) for the rules concerning institutional eligibility under Title IV. Also note that until 2005 for-profit institutions of higher education could not have more than 50 percent of their students engaged in "distance education,” now called "on-line coursework.” The rule was changed in 2005 and there were exemptions before that year. Large institutions now exist that are entirely on-line.
} 
programs in the state are offered by institutions that meet the requirement of having one program of sufficient length to apply for Title IV eligibility but are otherwise ineligible or choose not to participate.

Why might seemingly eligible institutions choose not to be eligible for Title IV student aid? For some, the costs of eligibility may be too high. Accreditation requires a significant amount of time and money and together with the administration costs of Title IV programs these may be prohibitive for small institutions. ${ }^{10}$ Alternatively, these schools might not gain sufficient financial benefit if their students are not disproportionately low-income or otherwise unqualified for federal aid. ${ }^{11}$ It should also be noted that many of the NT4 institutions do not have a 900hour program.

The structure and eligibility requirements of Title IV generate important incentives. Most important is that institutions that participate in Title IV programs may be able to increase tuition above cost and take part or the entire subsidy as profit or to use in other ways. Students eligible for a Pell grant or a subsidized loan in a T4 institution pay a net price equal to the listed tuition minus the value of the grant. In NT4 institutions, however, students pay the listed tuition. If the NT4 and T4 programs are equivalent and both are sold in the same market, then the arbitrage condition means that each charges the same net tuition to the student. The T4 institution would, then, increase tuition and the incidence of the subsidy will depend on the demand and supply elasticities.

The T4 institution could take its portion of the subsidy as profits or use it on recruitment, student services, or other activities. It is likely that both are occurring. Since this hinges on the ability of T4 institutions to enroll grant-eligible students, T4 institutions may engage in strategic

\footnotetext{
${ }^{10}$ To be accredited, schools must adhere to a set of common standards outlined by an accrediting agency. Standards vary by field and agency but typically involve requirements for mission statements, instructor qualifications, curriculum, admissions, facilities, and financial management. Costs of accreditation vary, often with the size of the program, and appear to be $\$ 5 \mathrm{~K}$ to $\$ 10 \mathrm{~K}$ for the initial fee. Schools must keep adequate records to obtain and maintain accreditation, just as they must for Title IV eligibility.

${ }^{11}$ One requirement for Title IV funding is that the student must have a high school diploma, GED, or pass an exam, termed the "ability to benefit" test, administered by the institution. In light of this restriction, it may be that NT4s attract students who do not have high school diplomas and would not be eligible for aid in any case. Reports of fraud in "ability to benefit" tests have led to a recent decision to eliminate the test (and consequently restrict federal aid only to high school graduates), perhaps making it more likely that NT4s will absorb high school dropouts in the future (GAO 2009; Nelson, 2012).
} 
recruiting. For example, they may locate in low-income neighborhoods or actively recruit students who meet the need-based aid criteria (Cellini 2010). They may also recruit military veterans eligible for the GI Bill, a source of federal aid that does not count toward the 90 percent aid threshold under Title IV. ${ }^{12}$

Title IV also gives incentives to institutions to provide services to ensure that students succeed in the labor market, at least during their first few years out when the schools can be held accountable for excessive defaults. ${ }^{13}$ If T4s spend more on student services or career counseling than NT4s, they should eventually drive many NT4s out of the market. And if T4 institutions, instead, take the subsidy as profits generating large gains for investors, they and other T4 institutions have an incentive to expand to the detriment of the NT4s. Exactly how and why NT4 institutions continue to survive in this market remains an open question.

Previous research on the Bennett hypothesis has focused primarily on four-year public and non-profit colleges with mixed results. Long (2004a) finds no evidence of tuition responses to federal higher education tax benefits among private and public four-year colleges and only limited evidence of tuition increases among public two-year colleges. In contrast, Singell and Stone (2007) report that grant aid raises tuition nearly dollar for dollar among private four-year colleges and that public institutions raise non-resident tuition in response to federal aid. Rizzo and Ehrenberg (2004) also find support for the Bennett hypothesis among public flagship fouryear colleges, but they report effects on in-state tuition rather than out-of-state tuition.

Several studies have looked beyond changes in tuition, to evaluate price responses on other margins, such as institutional aid and room and board fees. Turner (2012) finds that taxbased federal student aid crowds out institutional aid almost one for one in four-year colleges. Long (2004b) finds evidence that public four-year colleges increase room and board charges but not tuition, in response to Georgia’s HOPE merit scholarship program in the 1990s. Again, however, the evidence on non-tuition price responses is mixed. McPherson and Shapiro (1991)

\footnotetext{
${ }^{12}$ See http://frwebgate.access.gpo.gov/cgi-bin/getdoc.cgi?dbname=1999_register\&docid=99-19724filed.pdf on Title IV rules concerning loans and grants to veterans.

${ }^{13}$ See, for example, Rosenbaum, Deil-Amien and Person (2006) on the provision of services by the forprofits. The official Department of Education cohort default rate is calculated based on the two years after a student enters repayment.
} 
find that some four-year institutions actually increased institutional aid in response to federal aid. Reconciling these results, and shedding light on the for-profit sector, Turner (2011) finds that colleges have a positive willingness-to-pay for Pell Grant students, directing additional institutional aid to their neediest students. However, this willingness-to-pay is offset by federal aid capture. She finds that private nonselective non-profit institutions and for-profits behave similarly, capturing about 22 percent of student’s Pell Grant awards through reductions in institutional aid.

Most studies of the for-profit higher education sector have focused on T4 institutions. ${ }^{14}$ The U.S. Department of Education's Integrated Postsecondary Data System (IPEDS), the primary data set used by researchers studying the for-profit sector, includes mainly institutions that are Title IV eligible. The same institutions and their students form the basis for the Department's student-level surveys, such as the National Postsecondary Student Aid Study (NPSAS) and the Beginning Postsecondary Student Survey (BPS). Therefore, the most important national sources of information on the for-profit sector have virtually no information on NT4 institutions. We draw on administrative data we compiled from five states to estimate the total size of the for-profit sector and to explore tuition differences for comparable programs between T4 and NT4 institutions.

\section{Data on For-Profit Institutions, Students, and Tuition}

Almost every state has a private postsecondary regulatory agency devoted, at least in part, to for-profit institutions. The agencies require that postsecondary proprietary schools register with the state in order to operate, regardless of Title IV eligibility. Most state agencies collect and make public a list of open institutions each year, but few report detailed information on enrollments and programs-information we need to assess the overall size of the for-profit sector-and the tuition cost. ${ }^{15}$ In addition, we require that the information collected be

\footnotetext{
${ }^{14}$ On the Title IV for profits, see Bailey, Badway and Gumport (2001), Chung (2008, 2009), Deming, Goldin and Katz (2012), Rosenbaum, Deil-Amien and Person (2006), and Turner (2006). Research by Cellini (2009, 2010) on California suggested that the non-Title IV group is substantial.

${ }^{15}$ See Cellini, Davila and McHugh (2011) for a summary of every state's regulatory body and data availability. Some states include institutions with no enrollments but that have not yet formally closed.
} 
accessible either in electronic form or in a form we could obtain and easily manipulate. Five states meet these requirements. We analyze data on T4 and NT4 for-profit postsecondary institutions registered in Florida, Michigan, Missouri, Tennessee, and Wisconsin.

Table 1 describes the data availability for each state. Florida has the most comprehensive data with five years (2005 to 2009) of enrollment and program data covering all for-profit institutions. Data on programs include six-digit Classification of Instructional Programs (CIP) codes, clock or credit hours for each program, the degree type (e.g., AA, diploma, certificate), and tuition. The other states in our sample have similar, but less complete, program information.

Title IV eligibility by school must be inferred in these data for all states except Wisconsin, which reports whether a school is eligible for federal funding under Title IV. The other four states request that the institution list all valid accreditation through accrediting agencies approved by the U.S. Department of Education. We assume that properly accredited institutions are Title IV eligible. Accreditation is required for Title IV eligibility and is relatively expensive for small institutions. Only a rare institution, which met the other considerations for eligibility, would obtain accreditation unless it intended to request Title IV eligibility. To check this presumption we examined the most recent IPEDS listing and a list of all institutions receiving Pell Grants. We find that the vast majority of institutions in our state data listed as having valid accreditation are also Title IV eligible. ${ }^{16}$

Total program-level enrollment was fairly consistently reported across these states as a 12-month count, although Michigan listed the number of students starting a program, rather than enrollment. ${ }^{17}$ Wisconsin listed "prior" and "new" students, which were summed to obtain the total. Measures of program completion were more varied, with some states listing the number of graduates, completions, or the number of students considered “placeable.”

\footnotetext{
${ }^{16}$ In Florida, for example, 78 T4 institutions were listed in the state data for 2008. We located most by name and zip code (states do not always use U.S. Department of Education codes) in the Pell Grant data set. Of the remaining group, all but two were branches and were found in other states or were listed by a parent company name. Our definition of Title IV eligibility may serve to attenuate differences we observe between T4 and NT4 institutions but the definition seems to be quite accurate.

${ }^{17}$ We compared the Michigan data to the IPEDS data and found that, on average, the number of "starts" was similar to the 12-month enrollment figure. The reason for the similarity is that the non-degree programs are almost always less than a year. It should be noted that the IPEDS does not give enrollment data by program, whereas some of these states do.
} 
Notably, as is common in most other states, four of the states in our sample (Michigan, Missouri, Tennessee, and Wisconsin) exempt institutions from registering if they are covered by other parts of the state's bureaucracy. Cosmetology schools are the largest group of exempt institutions. These schools are required to obtain a license from the state board of examiners and are not required to register with the post-secondary proprietary school division of the state. Further, graduates of these schools cannot practice their craft without passing the state license examination. For one or both of these reasons, most state for-profit licensing agencies do not collect information on cosmetology schools. To track these institutions, except in Florida where the state reports the information, we have used other methods described in the Data Appendix.

The types of for-profit institutions captured in the data vary by state (see Table 1). Michigan reports data on only for-profits that have non-degree programs (although these could be degree-granting institutions), while the other states include institutions offering only associate's degrees, bachelor's and graduate degrees, as well as those with non-degree programs. ${ }^{18}$ In producing aggregate figures for all states we supplement the state data with the IPEDS to have a complete count of the T4 institutions and students. For all states except Florida, where the data are reported, we add our estimate of the cosmetology schools and their enrollment. Other differences in the composition of institutions across states may exist, particularly as they relate to on-line institutions. ${ }^{19}$

Three of the states, Florida, Michigan, and Wisconsin, report tuition by detailed program and form the basis of our comparison of tuition by T4 and NT4 institutions. Finally, we supplement our tuition analysis with cosmetology licensing exam pass rates for 2007 to 2010 obtained from the Florida Department of Business and Professional Regulation.

\title{
III. A Comprehensive View of the For-Profit Higher Education Sector
}

\author{
Institutions, Enrollments, and Completions
}

\footnotetext{
${ }^{18}$ We drop bachelors and graduate degree programs in our analysis of tuition, but we include all students in our enrollment counts.

${ }^{19}$ In Wisconsin on-line institutions are required to register with state regulatory agency if they offer programs to Wisconsin students. The other states do not appear to have requested this information.
} 
How large is the for-profit higher education sector? And how do NT4 institutions and enrollments compare with those that are Title IV eligible? Table 2 documents the raw and fulltime equivalent enrollments and completions, as well as the number of for-profit institutions in each of our five states. Although the five states differ in various ways that affect these data, it appears that many features of the for-profit sector are similar across the states.

In each of the states, the number of for-profit institutions at least doubles when the NT4 institutions are included (Table 1, rows 1 and 2). In all states except Florida, where the number of T4 and NT4 institutions are roughly equal, the NT4 institutions greatly exceed the T4 institutions. In Michigan NT4 institutions outnumber T4 institutions almost four to one, with NT4 institutions accounting for 80 percent of the total. Focusing solely on T4 institutions, as in most previous analyses, would vastly understate the number of for-profit post-secondary schools. In these five states alone, we would miss almost 1,200 schools each year.

Although the number of NT4 for-profit institutions is sizable relative to all for-profits, enrollment estimates are less understated because NT4 schools are smaller than the average Title IV for-profit. They would not include, for example, the large national and regional chains, although there are some chains among NT4 institutions. ${ }^{20}$ Across all five states, NT4 enrollments comprise between 12 and 66 percent of the total for-profit enrollment (Table 2, row 4). In most of the states, the NT4 schools have about 150 enrollees and the T4 institutions about 450. Florida has larger T4 institutions because many chains are located there.

NT4 students make up a larger share of completions than enrollments relative to the Title IV group (see rows 5 and 6 of Table 2) largely because of their shorter program length. There are more completions relative to enrollments each year for a one-year program than for a twoyear program, for example. In Florida in 2009 the ratio of completions to enrollments for the NT4 programs was 0.86 whereas the ratio for the T4 programs was 0.35 , even restricting the sample to non-degree programs and considering only programs with positive enrollments and graduates in each group.

To measure the intensity of education, rather than its incidence, we construct full-time

\footnotetext{
${ }^{20}$ We discuss chains in more detail below. We use the definition of a "chain” given in Deming, Goldin and Katz (2012).
} 
equivalent (FTE) enrollment and completion statistics by weighting enrollments and completions by program length. ${ }^{21}$ The adjustments, given in Table 2, rows (7) to (10), lower the proportion of enrollments and completions in NT4 programs, and in some cases the decrease is substantial. In Wisconsin, for example, the non-Title IV group accounts for 39 percent of for-profit enrollments in the raw data, but 15 percent when measured in FTEs. Completions drop from 72 percent in the raw data to 36 percent in terms of FTEs. Similar differences are found in the Florida data but the NT4 institutions are a lower fraction of the total compared with other states because Florida has more Title IV chains.

It is worth noting that Michigan has a disproportionate fraction of its total for-profit students and schools in the non-Title IV group even when expressed as FTEs. Of the for-profit post-secondary institutions in the state 75 percent are not Title IV eligible and 66 percent of the students attend NT4 institutions (53 percent on a FTE basis). One possible reason for the size of the non-Title IV for-profit higher education sector in Michigan concerns job training money provided by the state. In 2010 Michigan provided two years of free training (or $\$ 10,000$ per person) for unemployed and displaced workers. ${ }^{22}$ Displaced Michigan workers can also apply for Trade Adjustment Act funds, although the amount is low. The availability of state funds means that federally guaranteed loans may be less important for students in Michigan. Further, as we discuss below, the NT4 institutions in Michigan are well-established institutions and may have long-standing training relationships with automakers and other firms in the Detroit area.

Finally, using the data from the IPEDS for T4 institutions and the proportions of NT4 institutions in Table 2, we generate a rough estimate of the size of the whole U.S. for-profit sector. The IPEDS reports a total of 2,944 degree- and non-degree granting for-profit T4 institutions in 2009/10 (NCES 2010, tables 276 and 277). If NT4 institutions account for roughly 61 percent of the total (the average for the five states), our estimate of the entire forprofit sector becomes 7,549 institutions. Similarly, the inclusion of NT4 students raises the raw number of enrollments in for-profits, based on the IPEDS fall enrollment counts, from 1.8

\footnotetext{
${ }^{21}$ Specifically, we consider 600 clock hours or 24 credit hours to be full-time for a non-degree program and 900 clock hours or 45 credit hours to be full-time for degree programs. We use the IPEDS data on full-time equivalents for the T4 institutions for all states.

${ }^{22}$ See http://www.lcmw.org/pages/NWLBtraining.cfm for information on the Michigan Works! tuition assistance program.
} 
million to 2.47 million. The calculation assumes that NT4 institutions account for 27 percent (the average for the five states) of all enrollments or almost 670,000 students. $^{23}$ Our estimates suggest that studies that ignore NT4 institutions greatly understate the size of the sector.

\section{Program distribution}

To give a flavor for the range of programs offered by NT4 institutions, Table 3 lists the three largest programs by enrollment, and the fraction of all for-profit enrollments for each, in the states for which we have program data. ${ }^{24}$ The three largest programs in each state account for from 65 to 80 percent of the total enrollment in the NT4 group (Table 3, panel A). Further, the principal NT4 programs are fairly consistent across states. Business, computer, health, transportation, and personal and culinary services all represent a large share of the total NT4 enrollment in these five states.

Because the NT4 programs are almost entirely certificate or non-degree, the most relevant comparison is to the T4 non-degree programs. The T4 non-degree group is similarly dominated by health professions and personal and culinary services (see Appendix Table A2). These two program groups are about 75 percent of the total across the four states. Even though the NT4 institutions have relatively more non-degree enrollment in transportation and business than the T4 group, there is substantial overlap in the programs offered by the non-degree T4 and the NT4 institutions.

The next point to note is that NT4 institutions are a substantial fraction of all for-profit enrollments in their primary areas (Table 3, panel B). Consider the health professions group: in Michigan and Wisconsin the NT4 institutions account for more than 40 percent of the total forprofit enrollment in the health programs. Although transportation and materials moving is a

\footnotetext{
${ }^{23}$ We acknowledge that these five states may not be representative of the United States as a whole. We justify the use of the five-state data in generating national averages by the fact that the fraction of T4 forprofit enrollments per-capita (among 15 to 24 year olds) in these five states is approximately the same as it is in the entire United States (6.11 per 1000 in the five states and 6.05 for the entire United States). Note that 12-month enrollment counts are unavailable for non-degree institutions. Fall enrollment counts will understate the total because of the shorter programs and multiple enrollment dates over the year.

${ }^{24}$ For a full list of the programs by two-digit CIP code and fraction of all for-profit enrollments and completions in the NT4 group see panels A and B of Appendix Table A1. Panels C and D contain the same calculation where the underlying data are in FTE form. The share of NT4 and T4 enrollments represented by each program are reported in Appendix Table A2.
} 
smaller share of all NT4 enrollments than is health it is dominated by NT4 institutions, which are 80 and 90 percent of the group's enrollments in Florida and Tennessee. Omitting students in programs that do not participate in Title IV, leaves out many certificate-seeking students in some of the most important non-degree for-profit programs.

\section{IV.Tuition Differences between Title IV and Non-Title IV Institutions}

We now turn to our estimates of the difference in tuition charged by T4 and NT4 forprofit institutions for similar programs and untangle some of the possible explanations for these differences.

\section{Methods}

Our analysis of the role of Title IV in tuition-setting is limited to the three states in our sample that provide tuition data by program: Florida, Michigan, and Wisconsin. We analyze each state separately, but our approach is similar for each. We describe our general empirical model in the context of the Florida data (the state with, by far, the richest data), then discuss modifications to our approach for Michigan and Wisconsin.

To accurately identify the causal effect of Title IV eligibility on tuition levels, the ideal experiment would randomly assign Title IV eligibility across institutions and/or over time. In the absence of that experiment our analysis relies on a number of observable controls and fixed effects. Our results can be interpreted causally with some caution. Nonetheless, we produce an estimate of the premium to Title IV eligibility for similar programs by controlling for many differences in the programs offered by T4 and NT4 institutions, including school quality.

For Florida we estimate regressions of the following form:

$$
\begin{aligned}
& \text { Ln(tuition } \left._{\text {sitc }}\right) \\
& \qquad=\beta_{0}+\beta_{1}\left(\text { Title IV } V_{\text {st }}\right)+\beta_{2} X_{s i}+d_{i}+d_{t}+d_{t}\left(\text { Title IV } V_{s t}\right)+d_{c}+\varepsilon_{\text {sitc }}
\end{aligned}
$$

where Title IV equals one if an institution lists accreditation, zero otherwise for school $s$ in year $t$. Our dependent variable is the natural $\log$ of tuition in school $s$, program $i$, year $t$, and county $c$. 
$X$ is a vector of school and program characteristics, including the natural log of program length, the number of years the institution has been open, the natural log of enrollment, and whether the institution is part of a chain. Program length is measured as a proportion of full-time clock or credit hours. ${ }^{25}$ Years open is the number of years since the institution was first licensed by the state. Enrollment is a factor in determining the average cost of education and may reflect a program's reputation. Both mechanisms should influence tuition, but have no impact on Title IV eligibility. ${ }^{26}$ We code schools as being part of a chain if they operated in at least two states or had more than five branches within a state. ${ }^{27} d_{i}$ is a vector of indicator variables for each program measured by six-digit CIP codes. $d_{t}$ is a vector of year fixed effects to control for common time trends and is interacted with the Title IV indicator, when we have sufficient years, to see if the impact of Title IV status changes over time. $d_{c}$ is a county-level fixed effect, to control for competition among institutions in the same geographic market. ${ }^{28}$

We estimate eq. (1) for the full sample of two-year and non-degree for-profit programyears in each state. With the county, year, and six-digit CIP code fixed effects, identification comes from differences in tuition between T4 and NT4 institutions for the same programs (e.g., medical assisting) in the same year and county. We cluster the standard errors at the school level to account for correlation between programs in the same institution.

Our approach can control for many observable characteristics of programs that might be correlated with both tuition and Title IV status. Sample selection problems will remain if T4 programs and institutions are meaningfully different from NT4 programs and institutions. To address the issue of selection we test the robustness of our estimates to several different sample

\footnotetext{
${ }^{25}$ We have also estimated the regressions with program length as six dummy variables and the results do not materially change.

${ }^{26}$ As a robustness check, we added a potentially endogenous variable- - the number of program completions - to the model as a proxy for program quality. Its inclusion had virtually no impact our results in any state or specification. In addition, results are similar without the variable on enrollments. ${ }^{27}$ Deming, Goldin and Katz (2012) defines a "national chain" as a for-profit institution that operates in at least three separate census divisions and a "regional chain" as one that operates in more than one state or has more than five campus branches within a single state and operates in no more than two census divisions. We define the schools that meet either of these criteria as chains. See Data Appendix for more information on coding chains.

${ }^{28}$ City and zip code fixed effects yielded almost identical estimates in every state.
} 
restrictions and we control for quality of institution in two ways. ${ }^{29}$

Our first goal is to create a sample of T4 and NT4 programs that are comparable along as many dimensions as possible, so that we are comparing "apples to apples.” In some cases we restrict NT4 institutions to those that meet the requirement for Title IV eligibility of offering at least one program of at least 900 clock hours (or 45 credit hours), which is also one way to control for the quality of the institution. We then further limit the sample to full-time programs within those institutions. Our full-time designation requires that programs be at least 600 clock hours (or the equivalent) — the full-time definition under Title IV rules for non-degree programs. Our next restriction limits the sample to non-degree programs (e.g., programs that offer diplomas or certificates rather than associate's degrees) that are full-time and are in institutions offering at least one 900 clock-hour program. A final restriction is that we use only programs within the two-digit CIP code having the most observations in each state's data to compare T4 and NT4 programs that are similar.

Our next goal is to control for institution quality since unobservable differences between T4 and NT4 institutions may still remain even with the many controls we add. We have two ways of addressing the issue of quality. The first uses within school estimates of the tuition difference between eligible and ineligible programs in T4 schools. To implement this approach, we add institution fixed effects to eq. (1) and replace Title IV with an indicator for eligibility that equals one for programs that are at least 300 hours in length. We compare our estimates for T4 schools to a falsification test among the NT4 schools, in which all programs are ineligible. The second method uses state cosmetology licensing exam pass rates as a measure of school quality. We assess the impact on the T4 tuition premium of pass rates for full-time non-degree cosmetology programs.

\section{Florida}

In the Florida data, our main analytical sample of sub-baccalaureate for-profit programs contains 8,613 school-program-year observations, of which 3,373 are in NT4 institutions. Average tuition in T4 programs is about $\$ 17,000$ compared with $\$ 3,500$ in institutions that do

\footnotetext{
${ }^{29}$ We focus exclusively on two-year associate's degree and certificate and diploma (non-degree) programs since very few bachelor's and master's programs do not participate in Title IV.
} 
not participate in federal aid programs (Table 4, panel A). But NT4 programs are shorter (on average about 300 hours compared with 900 hours for T4 programs), have lower enrollment (50 students compared with 105), and are less likely to be given by an institution that is part of a chain (17 percent compared with 49 percent). ${ }^{30}$

Panel B of Table 4 compares the means of the T4 and NT4 group among a more limited sample. As noted above, in some specifications we restrict the regression analysis sample to full-time non-degree programs in schools that offer at least one program of 900 or more clock hours. But to more accurately reflect the sample used for identification in the analysis, we further limit the set of programs to those that contribute to identification when CIP code fixed effects are included. That is, we limit the sample to the set of programs in six-digit CIP codes that have at least one T4 and one NT4 program. We call this the "overlap" sample. ${ }^{31}$

We identify program "overlap” for fully 78 percent of the program-school observations in the Florida data for 2009 even though a large number of program codes have no overlap (159 of the 229 six-digit CIP codes). Most schools offer programs in the 70 remaining overlap program areas, independent of Title IV eligibility. ${ }^{32}$ After all of the restrictions in Table 4 panel B are imposed, we are left with 365 NT4 program-years and 1,549 T4 program-years. Mean differences are generally smaller in the restricted sample, particularly for tuition and length.

Finally, in Table 4 panel C, we compare the means of our most restrictive sample: fulltime, non-degree cosmetology programs in schools with at least one program of 900 or more hours. Cosmetology programs are relatively homogeneous. ${ }^{33}$ As reported in Table 4 panel C, limiting the sample to cosmetology programs results in a far smaller sample (139 NT4 and 608 T4 programs) and narrower differences in covariate means, most notably tuition (about \$3,900).

\footnotetext{
${ }^{30}$ In Table 4 (and throughout) length is measured as a proportion of a full-time program, which we define as 600 clock hours (i.e., 600 clock hours $=1$; 900 clock hours $=1.5$ ).

${ }^{31}$ In our regression analysis we include programs without overlapping CIP codes to aid in the identification of other covariates. Restricting the sample to the overlap group does not change our results. ${ }^{32}$ Of these, 129 have only T4 schools and 30 have only NT4 schools.

${ }^{33}$ The six-digit cosmetology code does encompass hair, nail and facial programs. Other popular programs, such as computer installation and repair, data entry and micro-computer applications, web page design, dental assisting, nursing assistant, and medical assistant have more heterogeneity in program type and length even within the six-digit CIP-code.
} 
We focus on cosmetology because it is the most numerous of the six-digit CIP codes among for-profit career colleges in Florida and in the nation and because its training leads to the taking of a state exam, the passing of which is required to practice the trade. ${ }^{34}$ For occupational programs like cosmetology, exam pass rates should be a good indicator of educational quality and are typically available to prospective students. ${ }^{35}$ We draw on pass percentages for 2007 to 2010 by school that we obtained from the Florida Department of Business and Professional Regulation. As shown in Table 4, panel C, mean pass percentages across all years for T4 and NT4 institutions are remarkably similar at 67 percent and 63 percent, respectively.

\section{Michigan}

As described earlier, our Michigan data are somewhat less rich than our Florida data and the sample is considerably smaller. In consequence, we modify our regression analysis. We continue to estimate a specification similar to equation (1), however, we have only one year of data. Because the data include only schools having non-degree programs, we have few chains in the Michigan data since they often grant only BA and AA degrees. We include, as we did for Florida, the number of years that an institution has been licensed by the state.

Our samples are also slightly different than those used in our Florida analysis. As noted in Table 1 and described above, our Michigan data are limited to non-degree programs, so even our broadest “full sample” excludes associate’s degree programs. Following our Florida analysis, we restrict the sample to institutions offering at least one program of 900 or more hours and then to programs that are full-time (600 or more hours for non-degree programs). Finally, since we do not have information on cosmetology programs we further limit our analysis to the most frequent two-digit CIP code, which in this case is health and medical programs. We note, however, that this two-digit CIP code contains a diverse set of programs including dental assistants, ultrasound technicians, and nursing assistants.

\footnotetext{
${ }^{34}$ Cosmetology (CIP codes 120401 or 120403 ) is the primary program offered in about 55 percent of all T4 for-profit institutions nationwide using the IPEDS data for years from 2005 to 2008.

${ }^{35}$ One potential complication is that there may be differential selection into test-taking across T4 and NT4 institutions. We find, however, that test takers exceed "completers" for both T4 and NT4 programs for 2007, 2008, and 2009 (years for which we have both the completions and exam data). Considering only those in "cosmetology" programs and omitting seven extreme outliers, we find that the ratio of exams to graduates among the T4 programs is 1.77 and that among NT4 programs is 2.15 averaged across the three years. The higher number of exams is possibly because of the theory and practical test portions.
} 
As shown in Table 5 panel A, we observe 456 NT4 programs in Michigan and 151 T4 programs in the full sample. As in the Florida data, unadjusted tuition differences are large and programs offered by T4 institutions cost more than five times those in the NT4 group. We emphasize that these raw differences vastly overstate the tuition premium we will identify for observationally identical programs. Not surprisingly, T4 institutions have been in operation much longer than NT4 institutions (11 years compared with 28 years). ${ }^{36}$ But to be eligible for Title IV status an institution has to be open for a minimum of only two years, suggesting that many NT4 institutions go well beyond the two-year timeframe without qualifying to have their students participate in the aid programs.

\section{Wisconsin}

Our Wisconsin data, like those for Michigan, are more limited than are those for Florida. As in Florida, we include county and year fixed effects as we have data for three years. Because Wisconsin did not provide CIP codes we inferred them at the two-digit level from program names. Our Wisconsin models therefore include fixed effects for each inferred two-digit CIP code. Our covariates include program length, enrollments, and chains. ${ }^{37}$

Our sample restrictions are similar to Florida, but we omit the restriction that a school must have at least one program longer than 900 hours because of the smaller sample size. ${ }^{38}$ We maintain the restriction of being full-time and having only non-degree programs and we also conduct separate analyses for medical and health-related programs, as we did for Michigan.

Panel B of Table 5 presents comparisons of means for the full sample of subbaccalaureate programs in Wisconsin. We observe 384 NT4 program-years and 577 T4

\footnotetext{
${ }^{36}$ Note that the average number of years since first licensure in Michigan is longer than the average in Florida. It appears that this is because Michigan required for-profits to register with the state several years before Florida.

37 "Years open" is not included since the year the school first registered was not listed for Wisconsin.

${ }^{38}$ Adding the full-time restriction eliminates about forty percent of programs in the full sample and about 60 percent of the (already small) non-degree sample. Using the 900 -hour restriction instead of the fulltime restriction yields similar results. Another complication in the Wisconsin data is that some nondegree programs are listed in terms of the number of "lessons" (ranging from 4 to 54) rather than clock hours or credit hours. In comparing programs with lessons and hours, it appears that a lesson is approximately equal to a credit hour or about 15 clock hours. We have used that equivalence to include programs with lessons.
} 
program-years. As in Michigan, tuition in T4 programs is considerably higher than in NT4 programs, uncorrected for various other factors. Of particular note is the extremely high proportion of NT4 institutions that are part of chains in Wisconsin (50 percent). Wisconsin requires that any out of state institution providing education to Wisconsin students, including online programs, be registered in the state. The same requirement was not in place or was not enforced in the other states.

\section{Tuition Difference Results for Three States}

Before we present results that compare tuition levels for comparable programs across schools that differ in Title IV eligibility, we must determine that the two types of institutions are sufficiently similar along several dimensions. We use the case of Florida since much of our analysis is for that state. In Table 6, we demonstrate that there is considerable overlap between the Florida T4 and NT4 institutions in program length, enrollment, years open, and even chain status. Both types of institutions offer at least one program of fewer than 300 hours (and therefore ineligible for aid) and both offer at least one program requiring 900 or more hours (and therefore potentially eligible for aid). Among the T4 schools, 27 percent offer short programs and fully 28 percent of the NT4 schools have a program of 900 or more hours.

Total institution enrollment also has common support across all categories, demonstrating that we are not simply comparing large chains to "mom-and-pop" schools. As would be expected, large chains are more common among T4s, just as mom-and-pop schools are more common among the NT4 group, but our comparisons are always at the program level.

The results of the regression analysis for the full Florida sample are given in Table 7. We include the log of program length plus county, year, year $\times \mathrm{T} 4$, and six-digit CIP code fixed effects in col. (1). Programs in T4 institutions charge about 38 log points (46 percent) more tuition than programs in NT4 institutions using this specification and adding (log) enrollment in col. (2) does not change the point estimate significantly. Adding the number of years open (i.e., years since first licensure) reduces the coefficient on tuition (col. 3) by a slight amount. The small point estimate on years open suggests that the longevity of an institution contributes little to tuition independent of Title IV status. Chains charge a premium of about $20 \log$ points, as shown in col. (4), and the inclusion of the variable moderately reduces the estimate of the 
correlation between tuition and Title IV status. ${ }^{39}$

Our analyses of the restricted samples in the Florida data are given in Table 8. Limiting the sample to the 5,195 program-years in institutions with at least one 900-plus clock-hour program, yields estimates remarkably similar to the full sample (41 log points). The Title IV premium increases substantially to $65 \log$ points (col. 2) when we restrict the sample to 3,577 full-time programs in this group. ${ }^{40}$ Restricting the sample further to non-degree programs (col. 3) has little impact on our estimate showing that the tuition difference is not because the T4 programs give more associate’s (AA) degrees.

In cols. (4) and (5) of Table 8 we present results by program clock hours to implement a falsification test. In col. (4) the tuition difference between the T4 and NT4 schools is 52 log points among programs lasting at least 300 clock hours. These programs should be eligible for some federal financial aid if the school itself is Title IV eligible. ${ }^{41}$ In contrast, in col. (5) we limit the sample to programs lasting less than 300 hours. Students in these short programs are ineligible for grant aid under Title IV even if the school is eligible. ${ }^{42}$ As expected, we find no significant difference within this group of ineligible programs. The evidence strongly suggests that the tuition difference is driven largely by the availability of student grant aid.

Of course, it is also possible that the tuition difference between T4 and NT4 institutions is driven by unobserved differences in school quality. That, however, does not appear to be the case because we find almost the same difference within T4 institutions for programs of different lengths (and thus different Title IV eligibility) as we do across institutions. We show this result in Table 9, col. (1), which has school fixed-effects and includes only T4 institutions. Even within T4 schools, programs lasting at least 300 hours have a 41 log point premium relative to those lasting less than 300 hours. Yet there is no difference for the NT4 schools (col. 2). This comparison provides our strongest evidence that T4s charge higher tuition because their students

\footnotetext{
${ }^{39}$ The interaction of the year dummy with T4 status is small and statistically insignificant in all columns and results are unchanged when we exclude these effects.

${ }^{40}$ The reason for the increase, as we will demonstrate, is that there is no T4 premium for short programs (fewer than 300 hours) since students enrolled in them cannot participate in Title IV student aid programs even if the school is Title IV eligible.

${ }^{41}$ Federal student aid for 300 to 599 hours programs would be for loans only and the program has to meet several other criteria.

${ }^{42}$ The same exercise cannot be done for Michigan and Wisconsin because the T4 samples are too small.
} 
are eligible for financial aid, not necessarily because they are higher quality institutions.

In Table 10 we present estimates using our most restrictive sample: full-time, non-degree cosmetology programs in institutions with at least one 900-plus clock-hour program. We find a 57 log-point premium to T4 eligibility (col. 1), a result that remains significant despite the small sample size. In cols. (2) to (5) we match our sample school-by-school to institutional records on cosmetology licensing exams to explore the question of school quality further. Because we lose 48 schools from the match, we also estimate the regression in col. (1) for the smaller matched sample, in col. (2). The results are approximately the same.

Another piece of evidence that quality is not driving tuition differences between T4 and NT4 institutions comes from including the percentage of students who pass the licensing exam for each school, as in cols. (3) and (4) of Table 10. Pass percentages are not significantly correlated with tuition and make little difference in our estimate of the Title IV premium (col. 3). Including an interaction term between pass percentage and Title IV (in col. 4) shows that the passing percentage matters far more for the NT4 than for T4 schools. If all students passed the exam, then the tuition gap would be 4.7 log points. ${ }^{43}$ The $\mathrm{T} 4$ institutions have a tuition premium of $54 \log$ points around the passing percentage mean of 65 percent. Below that pass percentage, the tuition gap widens. The T4 institutions may be advertising more and building reputation in other ways that account for their tuition premium at pass percentages below the very top.

As a final inquiry, we examine the role that competition plays in determining the T4 premium. It may be that in counties with more competing institutions, Title IV has less influence in tuition-setting. In col. (5) of Table 10, we therefore add the number of cosmetology schools in the county $(\times 10)$ and its interaction with Title IV. Our estimate of the tuition premium is virtually unchanged at $61 \log$ points and the coefficients on the number of institutions and its interaction with T4 are both small and insignificant, again suggesting that the premium we observe is attributable to Title IV status.

Overall, the evidence in Florida is remarkably robust, revealing that T4 institutions

\footnotetext{
${ }^{43}$ The Title IV eligible institutions have tuition that is $1.447 \log$ points higher but they lose $0.014 \log$ points for each pass percentage. If the pass percentage is 100 percent, T4 tuition is $(1.447-1.4=) 4.7 \log$ points more than NT4 tuition.
} 
charge roughly 60 log points more than NT4 institutions for similar programs.

Our analysis of the Michigan data in Table 11 yields similar results to those for Florida, with one complication. In Michigan, chain designation and Title IV status are highly collinear, particularly in our restricted samples. Almost all of the T4 institutions are part of a chain and few of the NT4 institutions are. We therefore report results both with and without the chain control. The broadest sample of non-degree programs in Michigan (in cols. 1 and 2), reveals a tuition difference of about 50 log points between T4 and NT4 institutions-well within the range of estimates for Florida. ${ }^{44}$ The estimates for schools with at least one 900 clock-hour program and for full-time programs within those institutions in cols. (3) to (6), yield estimates between 33 and $61 \log$ points, respectively. The inclusion of the chain variable results in smaller, insignificant point estimates on $\mathrm{T} 4$ but because about 75 percent of $\mathrm{T} 4 \mathrm{~s}$ are part of chains, the full effects are similar to those in cols. (3) and (5). ${ }^{45}$

Focusing only on Michigan's 67 full-time non-degree medical and health programs in schools with at least one 900-hour program reduces the tuition premium slightly to about 40 log points (cols. 7 and 8), but the difference remains significant at the 5 percent level even with the chain variable. As in Florida the years an institution has been open does not appear to be correlated with tuition. Our analysis for Michigan demonstrates that even in a state with a low fraction of all for-profit students in T4 institutions, Title IV eligibility still commands a premium.

In Table 12, we present results for Wisconsin. Tuition differences between T4 and NT4 institutions in the full sample are again highly significant but are much larger than those found in other states. Limiting the sample to full-time programs in col. (2) brings the tuition premium down to 84 log points. Restricting the sample to full-time, non-degree programs in col. (3) results in estimates in line with the other states $-61 \log$ points. Restricting the sample further to medical/health programs in col. (4) yields estimates around 74 log points.

Taken together our results are fairly consistent across states, samples, and specifications. We find highly statistically significant tuition premia for T4 institutions in almost all

\footnotetext{
${ }^{44}$ Results for alternative specifications are available on request.

${ }^{45}$ The full effect is $(0.75 \times 0.352)+0.329=0.593$, which is about the same as the coefficient on $\mathrm{T} 4$ in the other columns.
} 
specifications. Our smallest estimates, based on a heterogeneous group of institutions and programs in Florida, produce tuition differences of 30 log points. ${ }^{46}$ Our largest estimates, for a heterogeneous group of programs and institutions in Wisconsin exceed 100 log points. But, among a more comparable set of full-time, non-degree programs, our estimate range narrows to 61 to 74 log points. Our most reliable “apples-to-apples” estimates for full-time non-degree programs range from 52 to 65 log points (68 to 92 percent) across the three states.

In our most restrictive analysis, focusing only on Florida's full-time non-degree cosmetology programs in schools with at least one program of 600 or more clock hours, we observe a premium of about 58 log points (or 78 percent), similarly around the mean of the cosmetology passing percentage. We therefore consider 58 log points a fairly conservative "best estimate” of the average premium. Our analysis reliably controls for differences between T4 and NT4 programs across credentials, degrees, place, year, program length, enrollment, institutional age, and affiliation with a regional or national chain. Our results remain robust when we control for institution quality with school fixed effects and, for the cosmetology group, when we control for quality as measured by the passing percentage on the state licensing exam.

\section{Tuition Premia and Federal Student Aid}

How much of the difference in tuition between T4 and NT4 programs is accounted for by a typical federal student aid award? To make the comparison as close to "apples to apples” as possible we base our estimates on cosmetology programs. Table 4, Part C demonstrates that the mean difference in tuition between T4 and NT4 cosmetology programs is $\$ 3,903$ and that the average T4 cosmetology program (of about one year) costs $\$ 9,558$. According to the IPEDS, students in T4 for-profit less-than-two-year programs received on average \$3,390 in federal grant aid in 2007/08. ${ }^{47}$ Information on the 90/10 regulation indicates that about 75 percent of cosmetology revenue comes from federal financial aid, implying that loans account for another

\footnotetext{
${ }^{46}$ Note that the $30 \log$ point estimate includes short programs for which there are no tuition differences between the T4 and NT4 programs.

${ }^{47}$ The grant aid figure includes all federal grants, including the Pell Grant (under Title IV) and grants received through smaller programs, such as the GI Bill (NCES 2010, table 355).
} 
$\$ 3,780$. $^{48}$ We will assume that the average cosmetology student (in a Title IV eligible program) qualifies for the maximum amount of $\$ 3,500$ in federal government subsidized loans, a somewhat generous assumption. The current subsidy on loans is 3.4 percentage points. ${ }^{49}$ If the loan was paid back in equal amounts over four years, the additional subsidy from the lower interest rate would be about $\$ 300 .^{50}$ Total federal aid is then $\$ 3,690$, a figure very close to our empirical estimate of the tuition premium of $\$ 3,903$ and suggestive of the "Bennett hypothesis" of federal aid capture.

Because the average federal grant receipt by $\mathrm{T} 4$ students is approximately equal to the difference in tuition, the out-of-pocket price that students pay for equivalent T4 and NT4 programs is about the same. The arbitrage condition for these two types of institutions appears to hold.

What happens to the subsidy that comes from Title IV eligibility and thus the incidence of the subsidy? We must be agnostic on this issue because we do not observe the tuition levels before the subsidy. For-profit institutions may pocket the tuition difference. Alternatively, recent work by Deming, Goldin and Katz (2012) highlights the fact that T4 institutions spend a considerable amount to recruit and retain students. Large national chains spent about 24 percent of their revenue on sales and marketing (including advertising) in 2009. The average new student recruit costs these institutions a whopping $\$ 4,000$, a figure that is again roughly equal to the tuition premium we estimate using our most precise comparisons. ${ }^{51}$

Finally, institutions may incur additional costs to be Title IV eligible, a factor that may explain why some institutions that appear suitable for Title IV status choose not to apply. The costs includes obtaining accreditation by a recognized accrediting agency, which involves substantial fixed costs and is, in consequence, more expensive per student for small institutions. Other costs of Title IV eligibility include the administration of grants and loans. T4 institutions may also spend more money on student services, including child care and career services

\footnotetext{
48 "Proprietary School 90/10 Revenue Percentages from Financial Statements with Fiscal Year End Dates between 7/1/2010 and 6/30/2011," eZ-Audit as of 7/27/12.

${ }^{49}$ For loan rates see http://studentaid.ed.gov/types/loans/subsidized-unsubsidized

${ }^{50}$ Default would add to the subsidy, but that is a more tenuous calculation that we omit for simplicity.

${ }^{51}$ See Deming, Goldin and Katz (2012) for sources regarding this point.
} 
(especially important to ensure low default rates on federal student loans to maintain Title IV eligibility). But it seems unlikely that student services cover the full tuition premium.

\section{Discussion and Conclusion}

Generating an accurate count of the number of for-profit higher educational institutions and students has eluded researchers. With some exceptions, researchers have generally relied on U.S. Department of Education data that omits a large number of for-profit institutions that are not eligible to participate in federal student aid programs under Title IV of the Higher Education Act. In this paper, we draw on new state data to count these non-Title IV (NT4) institutions and generate what we believe to be the first comprehensive estimate of the size of the for-profit postsecondary education sector in the United States. We then investigate tuition differences between T4 and NT4 institutions to assess the claim that T4 schools raise tuition above the cost of education to capture federal aid.

We find that NT4 institutions do not appear to be transitional in nature or limited to a small number of institutions cycling in and out of eligibility. Rather, these institutions are a sizable portion of the for-profit market and many are long-lived. Accounting for NT4 institutions more than doubles the number of for-profit institutions reported in federal sources and increases enrollments by more than one-quarter.

We use our data to investigate the magnitude of the tuition premium for Title IV eligibility. We compare tuition at T4 institutions to that charged by NT4 institutions that appear to meet some of the requirements of Title IV. Using program, county, and year fixed effects as well as controls for enrollments and program length, among others, we find large and significant differences between the tuition charged by for-profit T4 and NT4 institutions. Our estimates are consistent across various states, specifications, and samples. T4 institutions charge about 58 log points, or 78 percent, more than NT4 institutions for comparable full-time non-degree programs in the same field. Our results hold even when we compare eligible and ineligible programs within the same T4 institutions and in our most restrictive sample when we control for the pass rate on cosmetology exams as an indicator of institutional quality. 
We have studied a case in which there are two suppliers of a service that receives a subsidy. Students at one type of institution can obtain a subsidy to pay for the service whereas students at the other cannot. As researchers, we cannot observe the price for both types of suppliers in the absence of the subsidy except in the case of short programs (fewer than 300 hours) ineligible for the subsidy. In those cases, the tuition charged by the two suppliers is nearly identical for the same programs. But when the subsidy is available, the difference-not unexpectedly - is almost identical to the subsidy. The fact that the difference in tuition is about the amount of the subsidy should not be surprising because it is the result of an arbitrage condition. What matters to the consumer (in this case a student) is the net price: gross tuition minus the amount of the subsidy.

We do not know the level of gross tuition in the absence of the subsidy and, therefore, do not know the degree to which tuition has increased at the T4 institutions because of the subsidy (and possibly decreased at the NT4 institutions). That is, we cannot measure the incidence of the subsidy. We do know that numerous NT4 institutions have existed for many years and do not appear to have greatly suffered in the absence of the subsidy. The implication is that students are indifferent between the two options since the net price is the same, and that the costs of provision are lower for the NT4s or else they would be losing out to the subsidized T4s. We have suggested that the two types of schools have different business models. For the T4s to utilize the subsidy they have to attract students who qualify for aid and that increases their costs due to recruiting and advertising.

We have considered the possibility that there are unobservable measures of reputation and quality that differ between T4 and NT4 institutions. But we find that even within T4 institutions, programs that are ineligible for Title IV student aid have tuitions that are identical to those offered by NT4 institutions. Further, we note that Title IV participation and accreditation come at a cost and that the tuition premium may, in part, reflect the added costs incurred by eligible institutions. The cost may also explain why some institutions that appear to meet eligibility requirements choose not to participate in Title IV programs.

Is our evidence consistent with the original Bennett hypothesis of federal aid capture? It could be. But the survival of the NT4s suggests that T4s increase their costs to take in federal 
aid. Our evidence is, therefore, consistent with a variant of the Bennett hypothesis.

In sum, institutions that are not part of the Title IV programs and their students are a sizable, but overlooked, part of the for-profit postsecondary education sector. In light of the U.S. Department of Education's recent move to tighten requirements for Title IV eligibility, forprofits that are not Title IV eligible may become a larger part of the for-profit market in future years. Our analysis suggests that these institutions can and do survive, and even thrive, alongside their aid-eligible counterparts. Further, since many NT4 institutions offer certificate programs similar to those in T4 institutions for a much lower (gross) price, our analysis implies that students who lose eligibility for Pell Grants and subsidized student loans due to the new regulations may be able to afford training in a for-profit institution that is not Title IV eligible. 


\section{References}

Bailey, Thomas, Norena Badway, and Patricia J. Gumport (2001). "For-Profit Higher Education and Community Colleges.” Stanford, CA: National Center for Postsecondary Improvement.

Cellini, Stephanie Riegg (2009). "Crowded Colleges and College Crowd-Out: The Impact of Public Subsidies on the Two-Year College Market,” American Economic Journal:

Economic Policy 1 (August), pp. 1-30.

Cellini, Stephanie Riegg (2010). "Financial Aid and For-Profit Colleges: Does Aid Encourage Entry?” Journal of Policy Analysis and Management 29 (Summer), pp. 526-52.

Cellini, Stephanie Riegg, Nicole Davila and Meghan McHugh (2011). "For-Profit Colleges in the United States: Research, Data, and Policy Recommendations.” Report to the Ford Foundation (January).

Chung, Anna S. (2008). “Effects of For-Profit College Training on Earnings.” Unpublished manuscript, University of Michigan, http://sitemaker.umich.edu/astchung/research

Chung, Anna S. (2009). “Choice of For-Profit College.” Unpublished manuscript, University of Michigan, http://sitemaker.umich.edu/astchung/research

Deming, David, Claudia Goldin and Lawrence F. Katz (2012). “The For-Profit Post Secondary School Sector,” Journal of Economic Perspectives 26 (Winter), pp. 139-64.

Deming, David, Claudia Goldin and Lawrence F. Katz (2013). “For-Profit Colleges,” The Future of Children, 23 (Spring), pp. 137-63.

Dynarski, Susan M. and Judith E. Scott-Clayton (2008). “Complexity and Targeting in Federal Student Aid: A Quantitative Analysis.” In J. Poterba, ed., Tax Policy and the Economy Vol. 22, pp. 109-150.

Government Accountability Office (GAO) (2009). “Proprietary Schools: Stronger Department of Education Oversight Needed to Ensure Only Eligible Students Receive Federal Student Aid.” GAO-09-600, August.

Guryan, Jonathan and Matthew Thompson (2010). “Comment on the proposed rule regarding Gainful Employment described in the NPRM released by the Department of Education on July 26, 2010.” Retrieved on October 15, 2010 from: www.regulations.gov (Document ID: 
ED-2010-OPE-0012-13610.1)

Long, Bridget Terry (2004a). "The Impact of Federal Tax Credits for Higher Education Expenses.” In C. Hoxby, ed., College Choices: The Economics of Where to Go, When to Go, and How to Pay for It. Chicago: University of Chicago Press and the National Bureau of Economic Research, pp.101-168.

Long, Bridget Terry. (2004b). "How do Financial Aid Policies Affect Colleges? The Institutional Impact of the Georgia HOPE Scholarship,” Journal of Human Resources, 39(3), pp. 104566.

McPherson, Michael, and Morton Owen Schapiro. (1991) Keeping College Affordable:

Government and Educational Opportunity. Washington, DC: The Brookings Institution.

National Center for Education Statistics (NCES) (2010). Digest of Education Statistics: 2010. Washington: U.S. Department of Education http://nces.ed.gov/programs/digest/d10/index.asp.

Nelson, Leslie (2012). “No Diploma, No GED, No Aid.” Inside Higher Ed. March 20, 2012. http://www.insidehighered.com/news/2012/03/20/colleges-worry-about-end-federal-aidbased-ability-benefit.

Rizzo, Michael J. and Ronald G. Ehrenberg (2004). "Resident and Non-Resident Tuition and Enrollment at Flagship State Universities.” In C. Hoxby, ed., College Choices: The Economics of Where to Go, When to Go, and How to Pay for It. Chicago: University of Chicago Press and the National Bureau for Economic Research, pp. 303-53.

Rosenbaum, James E., Regina Deil-Amien and Ann E. Person (2006). After Admission: From College Access to College Success. New York: Russell Sage Foundation Press.

Turner, Lesley (2011). "The Incidence of Student Financial Aid: Evidence from the Pell Grant Program.” Unpublished manuscript, Columbia University.

Turner, Nicholas (2012). "Who Benefits from Student Aid: The Economic Incidence of TaxBased Aid,” Economics of Education Review 31 (August), pp. 463-81.

Turner, Sarah E. (2006). "For-Profit Colleges in the Context of the Market for Higher Education." Chapter 3 of D. W. Breneman, B. Pusser, and S. E. Turner, eds., Earnings from Learning: The Rise of For-Profit Universities. Albany: State University of New York Press. 
Singell, Larry D. and Joe A. Stone (2007). "For Whom the Pell Tolls: The Response of University Tuition to Federal Grants-in-Aid,” Economics of Education Review, 26(3), pp. 285-95.

Skinner, Rebecca R. (2007). "Institutional Eligibility for Participation in Title IV Student Aid Programs Under the Higher Education Act: Background and Reauthorization Issues,” (March 9). Congressional Research Service Report for Congress. 
Table 1. Summary of Available For-Profit Data for Five States

Variables

Latest year for student data

Number of years of data available

\section{Title IV information}

Accrediting group

Eligible for federal funds

\section{Program information}

Program name

CIP (program) code

Clock hours, credit hours by program

Degree type

Tuition

\section{Student information}

Total enrollment

Total graduates ${ }^{\mathrm{c}}$

Enrollment, graduates by CIP code ${ }^{\mathrm{d}}$

Schools included in data

All (for-profit, public, non-profit)

For-profits only (all types)

For-profits non-degree only

Cosmetology schools included

Supplementary data from non-state sources

Licensing exam pass rates ${ }^{\mathrm{e}}$

IPEDS for-profit degree programs IPEDS/Google Maps for cosmetology

\begin{tabular}{lllll} 
FL & MI & MO & TN & WI \\
\hline
\end{tabular}

2008/09 2010 2007/08 $2009 \quad 2010$

$\begin{array}{lllll}5 & 1 & 1 & 1 & 3\end{array}$

\begin{tabular}{|c|c|c|}
\hline$\checkmark$ & $\checkmark$ & $\checkmark$ \\
\hline$\checkmark$ & $\checkmark$ & $\boldsymbol{V}^{\mathrm{a}}$ \\
\hline$\checkmark$ & $\checkmark$ & \\
\hline$\checkmark$ & & \\
\hline$\checkmark$ & $\checkmark$ & \\
\hline
\end{tabular}

$\begin{array}{lllll}\checkmark & \checkmark^{\mathrm{b}} & \checkmark & \checkmark & \checkmark^{\mathrm{b}} \\ \checkmark & \checkmark & \checkmark & \checkmark & \checkmark \\ \checkmark & \checkmark & & \checkmark & \checkmark\end{array}$


Table 2. For-Profit Post-Secondary School Students and Schools in FL, MI, MO, TN, and WI

\begin{tabular}{lllll} 
FL (2009) & MI (2010) & MO (2008) & TN (2009) & WI (2009) \\
\hline
\end{tabular}

Schools

(1) Total For-Profit (T4 +NT4)

671

(2) Fraction Non-Title IV

0.490

488

266

291

168

0.795

0.575

0.581

0.655

Enrollments

(3) Total For-Profit (T4 +NT4)

333,620

120,109

64,877

84,226

46,669

(4) Fraction Non-Title IV

0.115

0.656

0.242

0.296

0.393

Completions

(5) Total For-Profit (T4 +NT4)

91,360

79,588

25,078

23,201

18,865

(6) Fraction Non-Title IV

0.354

0.869

0.498

0.524

0.721

Full-time Equivalent (FTE) Enrollments

(7) Total For-Profit (T4 +NT4)

$304,792 \quad 54,836$

0.534

n.a.

n.a.

31,978

(8) Fraction Non-Title IV

0.044

n.a.

n.a.

0.152

Full-time Equivalent (FTE) Completions

(9) Total For-Profit (T4 +NT4)

66,777

36,241

0.152

0.744

n.a.

n.a.

7,165

(10) Fraction Non-Title IV

n.a.

n.a.

0.356

Notes : Years for the state data are given in parentheses. n.a. = data not available. TN and MO are missing information on programs and/or length. Because some of the state data includes only non-degree granting programs and most of these programs are Title IV eligible we used the IPEDS (for 2008) to obtain data on all Title IV institutions and exclude those already in the state data. We compute FTEs similar to the IPEDS by weighting enrollments (or completions) by program length scaled by the equivalent of 600 hours for non-degree programs and 900 hours for degree programs.

Source: State regulatory agencies. See Data Appendix. 
Table 3. Share of non-Title IV (NT4) Enrollments in Top Three Programs, by State

\begin{tabular}{|c|c|c|c|c|c|c|c|c|}
\hline \multirow[b]{2}{*}{ Program Name (CIP code) } & \multicolumn{4}{|c|}{ A. Program's Share of NT4 Enrollment } & \multicolumn{4}{|c|}{ B. NT4 Share of Program } \\
\hline & FL & MI & TN & WI & FL & MI & $\mathrm{TN}$ & WI \\
\hline Business, management, marketing (52) & & 0.255 & & 0.227 & & 0.878 & & 0.360 \\
\hline Computer and information sciences (11) & & 0.230 & & & & 0.785 & & \\
\hline Health professions (51) & 0.389 & 0.169 & 0.244 & 0.301 & 0.131 & 0.467 & 0.246 & 0.434 \\
\hline Personal and culinary services (12) & 0.295 & & 0.205 & 0.138 & 0.307 & & 0.894 & 0.479 \\
\hline Transportation and materials moving (49) & 0.119 & & 0.214 & & 0.797 & & 0.898 & \\
\hline $\begin{array}{l}\text { Total enrollment in NT4 accounted for by } \\
\text { the three major programs }\end{array}$ & 0.803 & 0.654 & 0.663 & 0.666 & & & & \\
\hline
\end{tabular}

Notes : For each state the three most important programs for the NT4 group by enrollment are given. Panel A reports the fraction of all NT4 enrollment in each of the three most important NT4 programs in that state (enrollment in program i/total NT4 enrollment). Panel B reports the fraction of all for-profit enrollment in that program accounted for by the NT4 institutions (NT4 enrollment in program i/total enrollment in program i in all for-profit institutions (NT4 + T4)).

Source: State regulatory agencies. See Data Appendix. 
Table 4. Mean Differences, Title IV and Non-Title IV Programs: Florida 2005-2009

\begin{tabular}{|c|c|c|c|c|c|c|c|c|c|}
\hline & \multicolumn{3}{|c|}{ A. All Sub-Baccalaureate Programs } & \multicolumn{3}{|c|}{ B. Hrs900, FT, Non-Deg, Overlap Prgms } & \multicolumn{3}{|c|}{ C. Hrs900, FT, Non-Deg Cosmetology Prgms } \\
\hline & $\begin{array}{c}\text { Non-Title IV } \\
\text { (sd) }\end{array}$ & $\begin{array}{c}\text { Title IV } \\
\text { (sd) }\end{array}$ & $\begin{array}{c}\text { Diff } \\
\text { (t-stat) }\end{array}$ & $\begin{array}{c}\text { Non-Title IV } \\
\text { (sd) }\end{array}$ & $\begin{array}{c}\text { Title IV } \\
\text { (sd) }\end{array}$ & $\begin{array}{c}\text { Diff } \\
\text { (t-stat) }\end{array}$ & $\begin{array}{c}\text { Non-Title IV } \\
\text { (sd) }\end{array}$ & $\begin{array}{c}\text { Title IV } \\
\text { (sd) }\end{array}$ & $\begin{array}{c}\text { Diff } \\
\text { (t-stat) }\end{array}$ \\
\hline Tuition & $\begin{array}{c}\$ 3,507 \\
(\$ 4,507)\end{array}$ & $\begin{array}{c}\$ 17,095 \\
(\$ 12,204)\end{array}$ & $\begin{array}{c}-\$ 13,589 \\
(73.2)\end{array}$ & $\begin{array}{c}\$ 5,907 \\
(\$ 4,679)\end{array}$ & $\begin{array}{l}\$ 12,332 \\
(\$ 5,689)\end{array}$ & $\begin{array}{c}-\$ 6,425 \\
(22.6)\end{array}$ & $\begin{array}{c}\$ 5,655 \\
(\$ 2,791)\end{array}$ & $\begin{array}{c}\$ 9,558 \\
(\$ 3,892)\end{array}$ & $\begin{array}{c}-\$ 3,903 \\
(13.7)\end{array}$ \\
\hline Length & $\begin{array}{c}0.5 \\
(0.6)\end{array}$ & $\begin{array}{c}1.5 \\
(0.7)\end{array}$ & $\begin{array}{c}-1.0 \\
(71.7)\end{array}$ & $\begin{array}{c}1.7 \\
(0.5)\end{array}$ & $\begin{array}{c}1.6 \\
(0.5)\end{array}$ & $\begin{array}{c}0.1 \\
(2.1)\end{array}$ & $\begin{array}{c}1.9 \\
(0.4)\end{array}$ & $\begin{array}{c}1.7 \\
(0.5)\end{array}$ & $\begin{array}{c}0.2 \\
(4.2)\end{array}$ \\
\hline Enrollment & $\begin{array}{c}50.98 \\
(115.67)\end{array}$ & $\begin{array}{c}105.05 \\
(187.26)\end{array}$ & $\begin{array}{l}-54.07 \\
(16.6)\end{array}$ & $\begin{array}{c}31.72 \\
(52.43)\end{array}$ & $\begin{array}{c}98.96 \\
(137.45)\end{array}$ & $\begin{array}{l}-67.25 \\
(15.1)\end{array}$ & $\begin{array}{c}30.53 \\
(39.28)\end{array}$ & $\begin{array}{c}77.33 \\
(111.70)\end{array}$ & $\begin{array}{c}-46.79 \\
(8.3)\end{array}$ \\
\hline Years open & $\begin{array}{c}7.38 \\
(5.81)\end{array}$ & $\begin{array}{l}11.57 \\
(8.93)\end{array}$ & $\begin{array}{l}-4.19 \\
(26.4)\end{array}$ & $\begin{array}{c}5.86 \\
(5.19)\end{array}$ & $\begin{array}{l}10.08 \\
(6.98)\end{array}$ & $\begin{array}{l}-4.22 \\
(13.0)\end{array}$ & $\begin{array}{c}6.96 \\
(5.91)\end{array}$ & $\begin{array}{c}9.69 \\
(6.36)\end{array}$ & $\begin{array}{l}-2.73 \\
(4.8)\end{array}$ \\
\hline Chain & $\begin{array}{c}0.17 \\
(0.37)\end{array}$ & $\begin{array}{c}0.49 \\
(0.50)\end{array}$ & $\begin{array}{l}-0.32 \\
(33.9)\end{array}$ & $\begin{array}{c}0.06 \\
(0.24)\end{array}$ & $\begin{array}{c}0.41 \\
(0.49)\end{array}$ & $\begin{array}{l}-0.35 \\
(19.7)\end{array}$ & $\begin{array}{c}0.03 \\
(0.17)\end{array}$ & $\begin{array}{c}0.25 \\
(0.43)\end{array}$ & $\begin{array}{l}-0.22 \\
(9.6)\end{array}$ \\
\hline PasspPercentage & & & & & & & $\begin{array}{l}62.6 \\
(17.1)\end{array}$ & $\begin{array}{l}66.7 \\
(11.5)\end{array}$ & $\begin{array}{l}-4.2 \\
(2.7)\end{array}$ \\
\hline Observations & 3,373 & 5,240 & & 365 & 1,549 & & 139 & 608 & \\
\hline
\end{tabular}

Notes: Observations are program-years. The sample in Panel A includes all associate's degree and non-degree (diploma or certificate) programs. Panel B restricts the sample to programs in schools with at least one program longer than 900 hours, those that are full-time, non-degree, and are classified in a 6-digit CIP code that has at least one T4 and one NT4 program (the overlap group). The sample in Panel C includes all of the restrictions in Panel B, but only cosmetology programs. Length is measured as a proportion of full-time enrollment, based on clock or credit hours. Years open are the number of years since first licensure. Chains are defined to be institutions operating in more than one state or with more than five campus branches in a single state.

Source: State regulatory agencies. See Data Appendix. 
Table 5. Mean Differences, Title IV and Non-Title IV Programs: Michigan and Wisconsin

\begin{tabular}{|c|c|c|c|c|c|c|}
\hline & \multicolumn{3}{|c|}{ A. All Non-Degree Programs, MI } & \multicolumn{3}{|c|}{ B. All Sub-Baccalaureate Programs, WI } \\
\hline & $\begin{array}{c}\text { Non-Title IV } \\
\text { (sd) }\end{array}$ & $\begin{array}{c}\text { Title IV } \\
\text { (sd) }\end{array}$ & $\begin{array}{c}\text { Diff } \\
\text { (t-stat) }\end{array}$ & $\begin{array}{c}\text { Non-Title IV } \\
\text { (sd) }\end{array}$ & $\begin{array}{c}\text { Title IV } \\
\text { (sd) }\end{array}$ & $\begin{array}{c}\text { Diff } \\
\text { (t-stat) }\end{array}$ \\
\hline Tuition & $\begin{array}{c}\$ 2,820 \\
(\$ 3,553)\end{array}$ & $\begin{array}{l}\$ 14,439 \\
(\$ 4,712)\end{array}$ & $\begin{array}{c}-\$ 11,618 \\
(27.8)\end{array}$ & $\begin{array}{c}\$ 4,552 \\
(\$ 4,327)\end{array}$ & $\begin{array}{c}\$ 25,203 \\
(\$ 10,653)\end{array}$ & $\begin{array}{c}-\$ 20,651 \\
(41.7)\end{array}$ \\
\hline Length & $\begin{array}{c}0.5 \\
(0.6)\end{array}$ & $\begin{array}{c}1.4 \\
(0.5)\end{array}$ & $\begin{array}{c}-0.9 \\
(17.2)\end{array}$ & $\begin{array}{c}0.5 \\
(0.7)\end{array}$ & $\begin{array}{c}1.8 \\
(0.9)\end{array}$ & $\begin{array}{c}-1.3 \\
(25.5)\end{array}$ \\
\hline Enrollment & $\begin{array}{c}69.50 \\
(185.07)\end{array}$ & $\begin{array}{c}101.79 \\
(125.96)\end{array}$ & $\begin{array}{c}-32.29 \\
(2.4)\end{array}$ & $\begin{array}{c}99.83 \\
(309.10)\end{array}$ & $\begin{array}{c}97.71 \\
(201.97)\end{array}$ & $\begin{array}{l}2.12 \\
(0.1)\end{array}$ \\
\hline Years Open & $\begin{array}{c}10.68 \\
(10.20)\end{array}$ & $\begin{array}{c}27.75 \\
(22.02)\end{array}$ & $\begin{array}{c}-17.07 \\
(9.2)\end{array}$ & & & \\
\hline Chain & $\begin{array}{l}0.08 \\
(0.27)\end{array}$ & $\begin{array}{c}0.72 \\
(0.45)\end{array}$ & $\begin{array}{l}-0.65 \\
(16.7)\end{array}$ & $\begin{array}{c}0.50 \\
(0.50)\end{array}$ & $\begin{array}{c}0.92 \\
(0.27)\end{array}$ & $\begin{array}{l}-0.42 \\
(15.1)\end{array}$ \\
\hline Observations & 456 & 151 & & 384 & 577 & \\
\hline
\end{tabular}

Notes: Observations are program-years. Panel A includes all non-degree (diploma/certificate) programs in Michigan in 2010. Panel B includes all associate's degree and non-degree programs in Wisconsin during 2008 to 2010. Length is measured as a proportion of full-time enrollment, based on clock or credit hours. Years open are the number of years since first licensure. Chains are defined to be institutions operating in more than one state or with more than five campus branches in a single state.

Source: State regulatory agencies. See Data Appendix. 
Table 6. Distribution of Title IV and Non-Title IV Institutions: Florida 2005-2009

Fraction

\begin{tabular}{|c|c|c|c|c|}
\hline & \multicolumn{2}{|c|}{ Frequency } & \multicolumn{2}{|c|}{ (Sums to 1 within categories) } \\
\hline & Non-Title IV & Title IV & Non-Title IV & Title IV \\
\hline Offer AA degrees & 10 & 107 & 0.03 & 0.40 \\
\hline Offer non-degree programs only & 297 & 160 & 0.97 & 0.60 \\
\hline $\begin{array}{l}\text { Schools with all AA and non-degree } \\
\text { programs }<900 \text { hours }\end{array}$ & 220 & 70 & 0.72 & 0.26 \\
\hline $\begin{array}{l}\text { Schools with at least one AA or non- } \\
\text { degree program } \geq 900 \text { hours }\end{array}$ & 87 & 197 & 0.28 & 0.74 \\
\hline $\begin{array}{l}\text { Schools with all AA and non-degree } \\
\text { programs } \geq 300 \text { hours }\end{array}$ & 54 & 195 & 0.18 & 0.73 \\
\hline $\begin{array}{l}\text { Schools with at least one AA or non- } \\
\text { degree program }<300 \text { hours }\end{array}$ & 253 & 72 & 0.82 & 0.27 \\
\hline Enrollment $<25$ & 88 & 20 & 0.29 & 0.07 \\
\hline Enrollment 26-50 & 63 & 21 & 0.21 & 0.08 \\
\hline Enrollment 51-100 & 57 & 40 & 0.19 & 0.15 \\
\hline Enrollment 101-200 & 40 & 55 & 0.13 & 0.21 \\
\hline Enrollment 201-500 & 45 & 64 & 0.15 & 0.24 \\
\hline Enrollment $>500$ & 14 & 67 & 0.05 & 0.25 \\
\hline Open $<2$ years & 50 & 25 & 0.16 & 0.09 \\
\hline Open 2-5 years & 96 & 58 & 0.31 & 0.22 \\
\hline Open 6-10 years & 89 & 85 & 0.29 & 0.32 \\
\hline Open $>10$ years & 72 & 99 & 0.23 & 0.37 \\
\hline Chain & 50 & 136 & 0.16 & 0.51 \\
\hline Non-Chain & 257 & 131 & 0.84 & 0.49 \\
\hline Observations & 307 & 267 & & \\
\hline
\end{tabular}

Notes: Observations are institutions. The sample includes all institutions that granted associate's degree and/or had non-degree (diploma and certificate) programs that were ever open from 2005 to 2009. Enrollment is the average enrollment across all programs in the time period we observe. Years open are those since first licensure. Chains are defined to be institutions operating in more than one state or with more than five campus branches in a single state. Source: State regulatory agencies. See Data Appendix. 
Table 7. Log Tuition Differences between Title IV and non-Title IV Institutions:

Florida, 2005-2009

All Sub-Baccalaureate Institutions and Programs

\begin{tabular}{lcccc} 
& $(1)$ & $(2)$ & $(3)$ & $(4)$ \\
\cline { 2 - 4 } Title IV & $0.376^{* * *}$ & $0.372^{* * *}$ & $0.346^{* * *}$ & $0.303^{* * *}$ \\
Ln (program length) & {$[0.065]$} & {$[0.064]$} & {$[0.067]$} & {$[0.070]$} \\
& $0.824^{* * *}$ & $0.823^{* * *}$ & $0.822^{* * *}$ & $0.817^{* * *}$ \\
Ln (enrollment) & {$[0.028]$} & {$[0.028]$} & {$[0.028]$} & {$[0.028]$} \\
& & 0.005 & -0.000 & -0.005 \\
Years open & & {$[0.012]$} & {$[0.013]$} & {$[0.013]$} \\
& & $0.006^{* *}$ & $0.005^{*}$ \\
Chain & & {$[0.003]$} & {$[0.003]$} \\
& & & $0.201^{* * *}$ \\
Six-digit CIP code FE & Yes & & & {$[0.068]$} \\
County FE & Yes & & & Yes \\
Year FE & Yes & Yes & Yes & Yes \\
Year $\times$ TitleIV FE & Yes & Yes & Yes & Yes \\
& & Yes & Yes & Yes \\
No. observations & 8,613 & & & 8,613 \\
R-squared & 0.872 & 8,613 & 8,613 & 0.875 \\
\hline
\end{tabular}

Notes: Standard errors in brackets, clustered by institution. ${ }^{* * *} \mathrm{p}<0.01,{ }^{* *} \mathrm{p}<0.05,{ }^{*} \mathrm{p}<0.1$

Sample includes all associate's degree and non-degree (diploma or certificate) programs in Florida for-profit institutions. Dependent variable is the natural log of tuition. Length is measured as a proportion of full-time enrollment, based on clock or credit hours. Years open are the number of years since the institution was first licensed. Chains are defined to be institutions operating in more than one state or with more than five campus branches in a single state. Programs with zero enrollment, tuition, or length are dropped. Omitted year is 2008/09.

Source: State regulatory agencies. See Data Appendix. 
Table 8. Log Tuition Differences between Title IV and non-Title IV Institutions, Restricted Samples: Florida, 2005-2009

\begin{tabular}{|c|c|c|c|c|c|}
\hline & \multicolumn{3}{|c|}{ School has at least one $900+$ clock-hour program } & \multicolumn{2}{|c|}{ Program clock-hours } \\
\hline & \multicolumn{3}{|c|}{ Full-time program } & \multirow[b]{2}{*}{$\geq 300$ hours } & \multirow{2}{*}{$\begin{array}{c}\text { Falsification: } \\
<300 \text { hours }\end{array}$} \\
\hline & & & Non-degree & & \\
\hline & $(1)$ & $(2)$ & $(3)$ & $(4)$ & $(5)$ \\
\hline \multirow[t]{2}{*}{ Title IV } & $0.413^{* * *}$ & $0.650 * * *$ & $0.646^{* * *}$ & $0.519 * * *$ & -0.143 \\
\hline & {$[0.100]$} & {$[0.082]$} & {$[0.066]$} & {$[0.070]$} & {$[0.101]$} \\
\hline \multirow[t]{2}{*}{ Ln (program length) } & $0.863 * * *$ & $0.987 * * *$ & $0.952^{* * *}$ & $0.875^{* * *}$ & $0.756^{* * *}$ \\
\hline & {$[0.058]$} & {$[0.073]$} & {$[0.046]$} & {$[0.041]$} & [0.082] \\
\hline \multirow[t]{2}{*}{ Ln (enrollment) } & 0.009 & $0.024^{*}$ & $0.038 * * *$ & 0.007 & $-0.061 * * *$ \\
\hline & {$[0.013]$} & {$[0.012]$} & {$[0.012]$} & {$[0.016]$} & [0.017] \\
\hline \multirow[t]{2}{*}{ Years open } & 0.004 & 0.005 & 0.002 & $0.006^{*}$ & $-0.009 * *$ \\
\hline & {$[0.004]$} & {$[0.004]$} & {$[0.002]$} & {$[0.003]$} & {$[0.005]$} \\
\hline \multirow[t]{2}{*}{ Chain } & 0.137 & 0.068 & 0.045 & $0.118 *$ & $0.261 * *$ \\
\hline & {$[0.084]$} & {$[0.065]$} & {$[0.051]$} & {$[0.067]$} & {$[0.105]$} \\
\hline Six-digit CIP code FE & Yes & Yes & Yes & Yes & Yes \\
\hline County FE & Yes & Yes & Yes & Yes & Yes \\
\hline Year FE & Yes & Yes & Yes & Yes & Yes \\
\hline Year $\times$ TitleIV FE & Yes & Yes & Yes & Yes & Yes \\
\hline No. observations & 5,195 & 3,577 & 2,664 & 5,870 & 2,743 \\
\hline R-squared & 0.855 & 0.702 & 0.773 & 0.736 & 0.787 \\
\hline
\end{tabular}

Notes: Standard errors in brackets, clustered by institution. ${ }^{* * *} \mathrm{p}<0.01, * * \mathrm{p}<0.05,{ }^{*} \mathrm{p}<0.1$

Observations are program-years. In col. (1) the sample is restricted to programs (part- or full-time) in schools with at least one program longer than 900 hours. In col. (2) the sample further restricted to only full-time programs (in addition to the school-level 900+ clock-hour restriction). The sample in col. (3) is further restricted to non-degree programs. In col. (4) the sample includes only non-degree programs that are less than 300 clock-hours and are therefore ineligible for Title IV student aid, even if the institution is eligible. The dependent variable in all estimations is the natural log of tuition. Length is measured as a proportion of full-time enrollment, based on clock hours or credit hours. Years open are the number of years since the institution was first licensed. Chains are defined to be institutions operating in more than one state or with more than five campus branches in a single state. Programs with zero enrollment, tuition, or length are dropped. Omitted year is 2008/09.

Sources: State regulatory agencies. See Data Appendix. 
Table 9. Within-School Log Tuition Differences between Title IV and non-Title IV Institutions: Florida, 2005-2009

\begin{tabular}{|c|c|c|}
\hline & T4 Schools Only & $\begin{array}{c}\text { Falsification: } \\
\text { NT4 Schools Only }\end{array}$ \\
\hline & $(1)$ & $(2)$ \\
\hline Eligible ( $\geq 300$ hrs) & $0.411^{* * *}$ & 0.051 \\
\hline & {$[0.072]$} & {$[0.128]$} \\
\hline Ln (program length) & $0.925^{* * *}$ & $0.768 * * *$ \\
\hline & {$[0.057]$} & {$[0.090]$} \\
\hline Ln (enrollment) & 0.003 & -0.025 \\
\hline & {$[0.008]$} & [0.017] \\
\hline School FE & Yes & Yes \\
\hline Six-digit CIP code FE & Yes & Yes \\
\hline Year FE & Yes & Yes \\
\hline No. obs./institutions & $5,240 / 267$ & 3,373/307 \\
\hline R-squared & 0.944 & 0.935 \\
\hline
\end{tabular}

Notes: Standard errors in brackets, clustered by institution. ${ }^{* * *} \mathrm{p}<0.01,{ }^{* *} \mathrm{p}<0.05,{ }^{*} \mathrm{p}<0.1$

The sample in col. (1) is restricted to sub-baccalaureate programs in Title IV institutions and the sample in col. (2) is restricted to those programs in non-TitleIV institutions. The main variable of interest, "Eligible," equals one for programs that are 300 clock-hours or longer and therefore may be eligible for Title IV aid. The dependent variable in all estimations is the natural log of tuition. Length is measured as a proportion of full-time enrollment, based on clock hours or credit hours. Years open are the number of years since the institution was first licensed. Chains are defined to be institutions operating in more than one state or with more than five campus branches in a single state. Programs with zero enrollment, tuition, or length are dropped.

Sources: State regulatory agencies. See Data Appendix. 
Table 10. Log Tuition Differences between Title IV and non-Title IV Institutions, Cosmetology Programs: Florida, 2005-2009

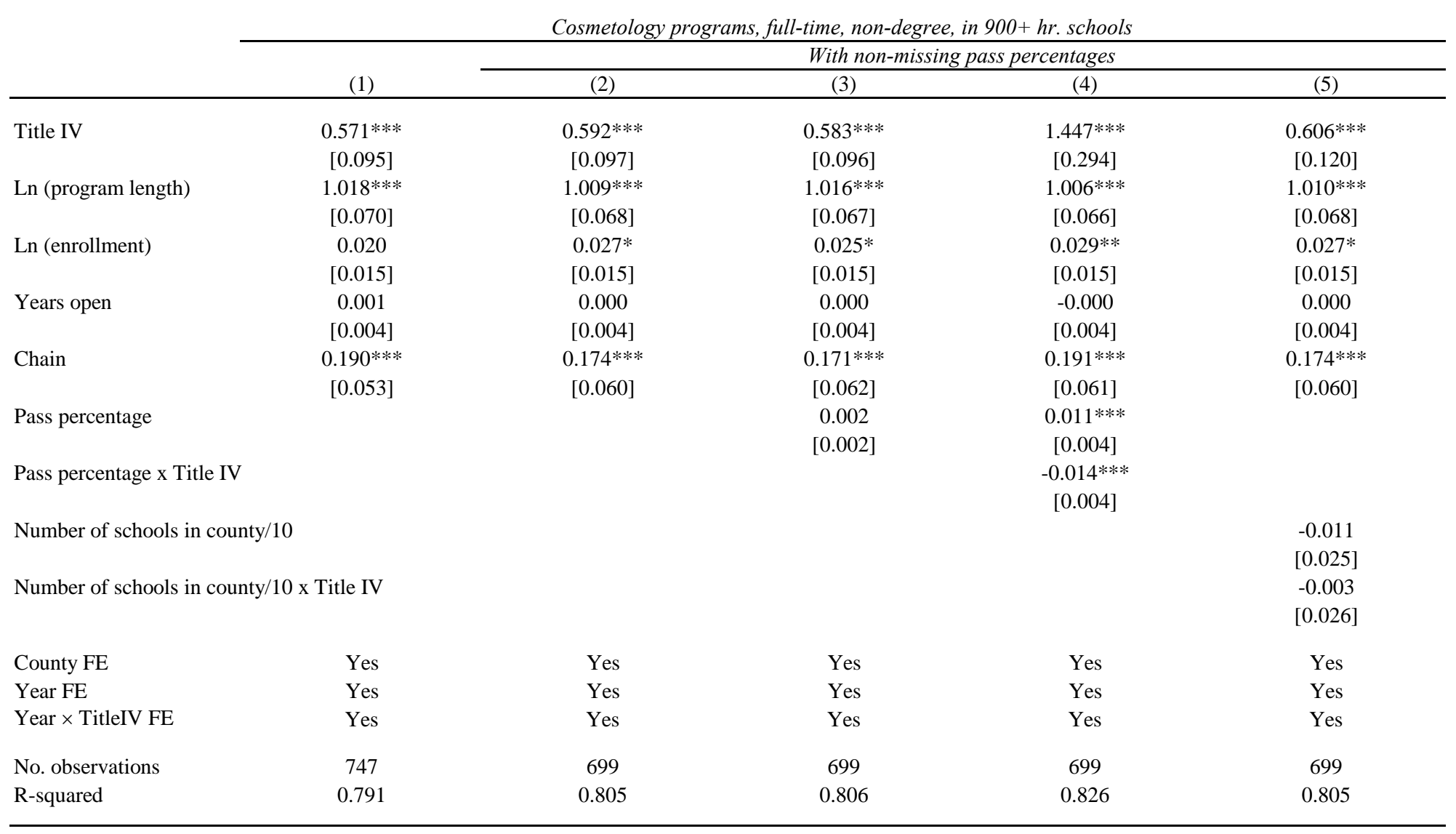

Notes: Standard errors in brackets, clustered by institution. ${ }^{* * *} \mathrm{p}<0.01,{ }^{* *} \mathrm{p}<0.05,{ }^{*} \mathrm{p}<0.1$

In col. (1), the sample includes only non-degree cosmetology programs that are full-time and are in schools with at least one 900+ clock-hour program. Cols. (2) and (3) restrict the cosmetology sample to include only those schools with valid pass rates on the state licensing exam. The dependent variable in all estimates is the natural log of tuition. Length is measured as a proportion of full-time enrollment, based on clock hours or credit hours. Years open are the number of years since the institution was first licensed. Chains are defined to be institutions operating in more than one state or with more than five campus branches in a single state.

"Number of Schools in County/10 × Title IV" is the number of cosmetology schools in the county divided by 10 interacted with an indicator for Title IV to measure the degree of competition in the county. Pass percentage is the average percentage passing the state licensure exam across all available years. Programs with zero enrollment, tuition, or length are dropped. The omitted year is 2008/09.

Source: State regulatory agencies. See Data Appendix. 
Table 11. Log Tuition Differences between Title IV and non-Title IV Institutions: Michigan, 2010

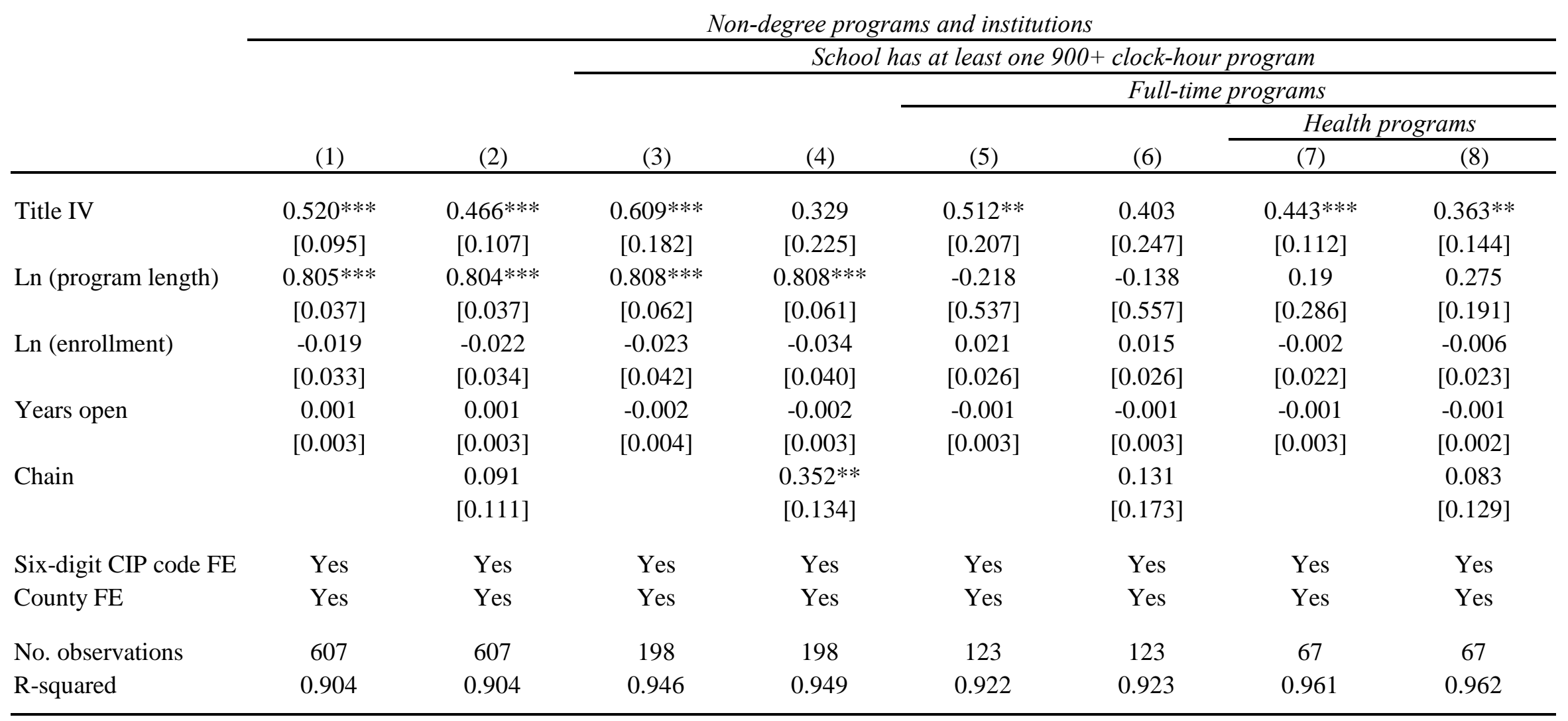

Notes: Standard errors in brackets, clustered by institution. ${ }^{* * *} \mathrm{p}<0.01,{ }^{* *} \mathrm{p}<0.05,{ }^{*} \mathrm{p}<0.1$

The sample in cols. (1) and (2) includes all non-degree programs (the Michigan data do not include degree programs). Cols. (3) and (4) include only programs in schools with at least one program 900+ clock-hours. Cols. (5) and (6) further restricts to full-time programs. Cols. (7) and (8) restrict to health or medical programs that are full-time and in schools wiht 900+hours (two-digit CIP code $=51$ ). Length is measured as a proportion of full-time enrollment, based on clock hours or credit hours. Years open are the number of years since an institution was first licensed. Chains are defined to be institutions operating in more than one state or with more than five campus branches in a single state. Programs with zero enrollment, tuition, or length are dropped.

Source: State regulatory agencies. See Data Appendix. 
Table 12. Log Tuition Differences between Title IV and non-Title IV Institutions:

Wisconsin, 2008-2010

All sub-baccalaureate institutions and programs

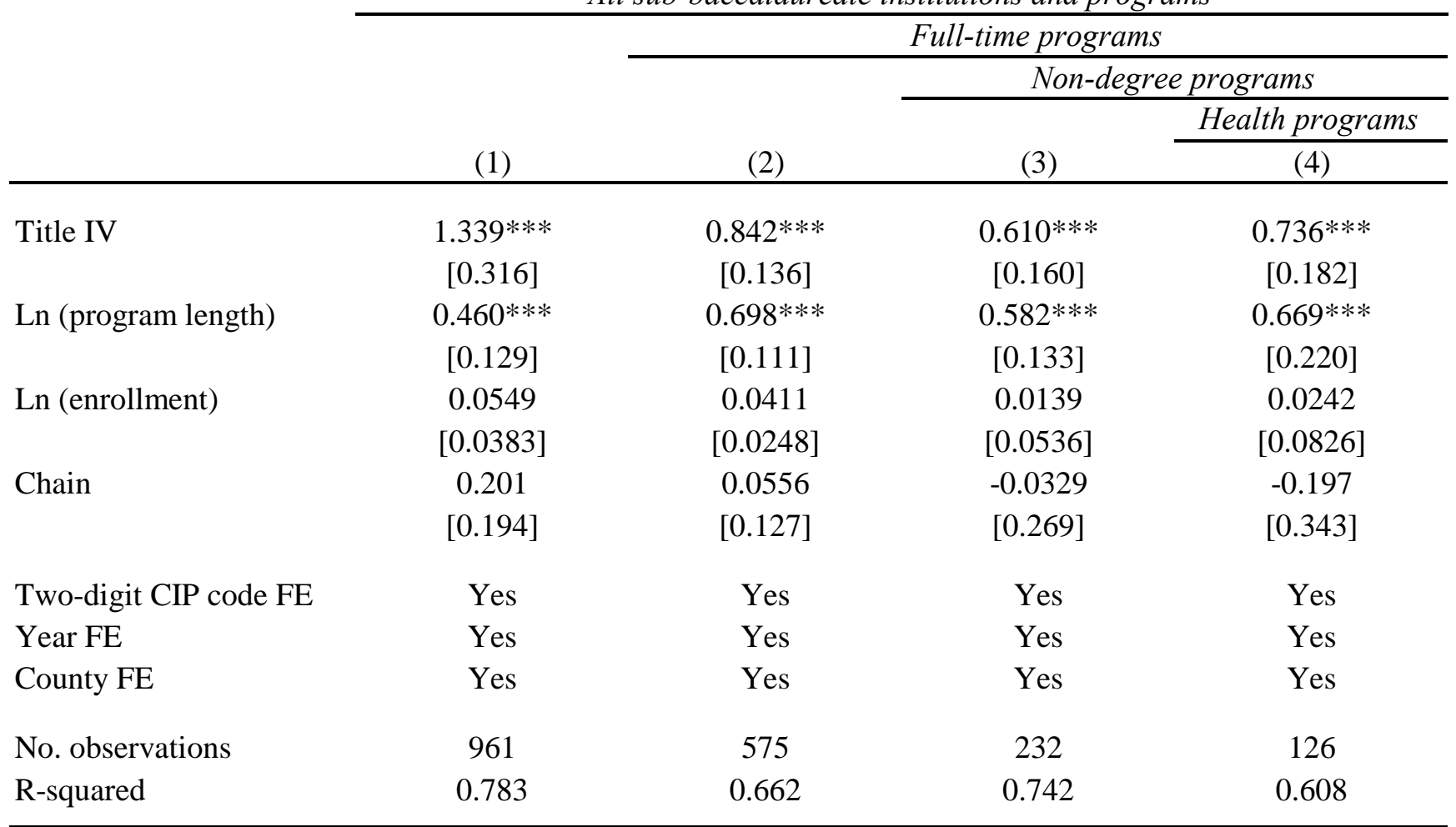

Notes: Standard errors in brackets, clustered by institution. ${ }^{* * *} \mathrm{p}<0.01,{ }^{* *} \mathrm{p}<0.05,{ }^{*} \mathrm{p}<0.1$

The sample in col. (1) includes all sub-baccalaureate programs (associate's degree and non-degree). Col. (2) restricts further to full-time programs. Col. (3) restrict further to non-degree programs. Col. (4) restricts only to health/medical professions that are full-time and non-degree (2-digit cip code $=51$ ). Length is measured as a proportion of full-time enrollment, based on clock hours, credit hours, or "lessons," which are assumed to be 15 clock hours per lesson. Chains are defined to be institutions operating in more than one state or with more than five campus branches in a single state. Programs with zero enrollment, tuition, or length are dropped. Source: State regulatory agencies. See Data Appendix. 


\section{Data Appendix}

Postsecondary school data sets by state

As described in the text, each state postsecondary school data set contains somewhat different information. The information we have used is summarized in Table 1. The states with readily accessible and reasonably complete data are FL, MI, MO, TN, and WI.

The FL data are the most complete and list all postsecondary institutions operating in the state, including cosmetology schools. The other states did not include cosmetology schools because the state board of examiners takes responsibility for them but does not have detailed information on them. We used a combination of methods to locate all of the cosmetology school including lists from the state board of examiners and web searches (e.g., Google maps). In most cases we had to estimate the numbers of enrollments and completions and our methods are listed below.

We generally inferred Title IV status from the variables listing accrediting agencies, although WI provided information on whether students in the institution were eligible for federal funds. In many cases we checked the most recent IPEDS listing to see if institutions were listed and, thus, were Title IV eligible.

Many of our calculations are straightforward. Enrollments are measured on a 12 month standard for most of the states. The only exception is Michigan, which reports "starts." We compared the Michigan data to the IPEDS data for some of these institutions and found that, on average, "starts" was similar to the 12-month enrollment figure. In the IPEDS, the "12-month, unduplicated headcount” is used.

Our calculation of full-time equivalents (FTE) is less straightforward. We are only able to compute FTE enrollments and completions in those states that had program-level data available because we scaled by clock hours or credit hours and these vary by program. We created a program length variable that is the proportion of each program's credit or clock hours relative to a full-time, 12-month instructional standard, depending on the information provided. The calculation follows federal classifications by assuming that a full-time degree-granting 
program is 900 contact hours per year (or 45 credit hours for undergraduates on quarter system calendars or 30 credit hours for undergraduates on semester system calendars) and that a fulltime non-degree granting program is 600 hours (or 24 credit hours for students on quarter system calendars or 16 credit hours for students on semester system calendars). For the few programs in Wisconsin reporting only "lessons," we used the conversion that a lesson equals a credit hour or 15 clock hours.

The FTE calculation affects only the non-degree (less than one-year or short) programs. The degree programs are generally meant to be more than one year in duration and the application of the 900 hour standard (or that concerning credit hours) would result in a figure greater than one. In those cases, we use the actual enrollment figure. We also did a robustness check using 900 hours (or its equivalent) for all programs. The results change only for the nondegree programs (for which we used the 600 hour figure) and the change is minimal. When we employ the IPEDS data, we use the IPEDS FTE data, although the IPEDS appears to add parttime student status in their calculation.

We used the U.S. Department of Education, NCES CIP (Classification of Instructional Programs) codes (see http://nces.ed.gov/pubs2002/cip2000/ciplist.asp) to classify the programs for FL and MI; for TN and WI we classified them ourselves using program descriptions since CIP codes were not given. MO did not have electronic data on programs.

Most of the states list only non-degree granting programs. Because most degree granting programs are Title IV eligible we used the IPEDS (2008) to obtain data on all Title IV institutions and exclude the overlap group when the state data includes some that are Title IV eligible. For some states, the state data are more recent than are the IPEDS data.

When cosmetology (and barbering) schools are excluded we obtained a count of these schools using various sources and subtract those that were already in the IPEDS data. Because the FL data contain all cosmetology schools, we used those data to get estimates of enrollments and completions, also as FTEs, for the non-Title IV group. Because we had data for the Title IV cosmetology schools in each state from the IPEDS, we used the ratio of the FL non-Title IV enrollments or completions to that for the Title IV schools and then scaled by the Title IV data in 
the states for which we did not have non-Title IV data. Similarly, we estimated FTEs in a similar manner.

To determine whether institutions were part of chains, we used the definition given in Deming, Goldin, and Katz (forthcoming), coding as chains institutions with branches in more than one state or more than five branches in one state as chains. For T4 institutions, we began with institutions identified by Deming, Goldin, and Katz as chains. We coded all NT4 institutions and some missing T4 institutions by hand. Our Wisconsin regulatory agency data provided information on each school's additional locations. In Michigan and Florida, we used the Internet to look up each school and its "campus locations” and/or address(es) to determine chain status according to our definition. For this reason, our chain determination for these states is based on the number of branches and states in 2012, rather than in each year in our data.

State licensing cosmetology exam pass percentages for Florida

We obtained XLS spreadsheets by fiscal year from 2007/08 to 2010/11 for all test takers by school from the Florida Department of Business and Professional Regulation, Division of Technology. (We purchased the data under the public records law of the state.) The data include all test takers and passes. Those taking the exam more than once after a failure are included, that is we do not have only first-time test takers. We matched schools by name and zip code. The existing records for the exams before 2007 were not collected by unique school name and are difficult to use. No identification numbers were given and the two agencies in Florida do not apparently coordinate on data collection. We averaged pass percentages by school for all years in the data set.

\section{Sources}

Florida: Florida Commission for Independent Education http://www.fldoe.org/cie/

The Commission provided us with four XLS files of their data.

Michigan: Michigan Proprietary Schools Unit

http://www.michiganps.net/ 
Michigan has a website listing its schools and the separate programs in each school, but they could not provide electronic data. Instead, we captured the website information on institutions and programs within each institution.

Missouri: Missouri Department of Higher Education

http://www.dhe.mo.gov/data/propstatsum.php

The website contains XLS files that provided our data.

Tennessee: Tennessee Higher Education Commission

http://www.state.tn.us/thec/Divisions/LRA/PostsecondaryAuth/psa.html

The TN Commission provided four XLS files with the data for all but the exempt (e.g., cosmetology) schools. State colleges and universities, small liberal arts universities, nonprofit organizations (e.g., Red Cross and United Way), and theological schools were removed for this project.

Wisconsin: Wisconsin Educational Approval Board

http://eab.state.wi.us/default.asp

The website contained a PDF file of schools and programs and the Board provided us with the electronic version of the file. 


\section{Appendix Table A1. Share of For-Profit Enrollments and Completions in Non-Title IV Institutions, by Program and State}

\begin{tabular}{lcccc}
\multicolumn{6}{l}{ A. Share of For-Profit Enrollments in Non-Title IV Institutions, by Program and State } \\
\hline Program (CIP codes) & FL & MI & TN & WI \\
\hline Agriculture (01) & 0.66 & 1.00 & 1.00 & 1.00 \\
Business (52) & 0.02 & 0.88 & 0.18 & 0.36 \\
Communications (09, 10) & 0.05 & 0.05 & 0.03 & 0.03 \\
Computer Science (11) & 0.12 & 0.79 & 0.17 & 0.07 \\
Construction (46, 48) & 0.08 & 0.84 & 0.03 & 0.78 \\
Engineering (14, 15) & 0.08 & 0.97 & 0.00 & 0.00 \\
Health (51) & 0.13 & 0.47 & 0.25 & 0.43 \\
Security \& Law Enforcement (43) & 0.01 & 0.96 & 0.02 & 0.00 \\
Mechanics (47) & 0.05 & 0.53 & 0.04 & 0.88 \\
Personal \& Culinary (12) & 0.31 & 0.54 & 0.89 & 0.48 \\
Religion (39) & 0.00 & 1.00 & 0.84 & 0.00 \\
Transportation (49) & 0.80 & 1.00 & 0.90 & 0.00 \\
Arts (50) & 0.04 & 0.30 & 0.02 & 0.65 \\
Other & 0.04 & 0.30 & 0.75 & 0.08 \\
\hline
\end{tabular}

B. Share of For-Profit Completions in Non-Title IV Institutions, by Program and State

\begin{tabular}{lcccc}
\hline Program (CIP codes) & FL & MI & TN & WI \\
\hline Agriculture (01) & 0.67 & 1.00 & 1.00 & 1.00 \\
Business (52) & 0.11 & 0.98 & 0.34 & 0.76 \\
Communications (09, 10) & 0.08 & 0.14 & 0.04 & 0.13 \\
Computer Science (11) & 0.45 & 0.96 & 0.46 & 0.21 \\
Construction (46, 48) & 0.20 & 0.98 & 0.14 & 0.98 \\
Engineering (14, 15) & 0.32 & 1.00 & 0.00 & 0.00 \\
Health (51) & 0.37 & 0.65 & 0.37 & 0.75 \\
Security \& Law Enforcement (43) & 0.11 & 1.00 & 0.13 & 0.00 \\
Mechanics (47) & 0.11 & 0.88 & 0.03 & 0.85 \\
Personal \& Culinary (12) & 0.50 & 0.69 & 0.98 & 0.37 \\
Religion (39) & 0.00 & 1.00 & 0.92 & 0.00 \\
Transportation (49) & 0.83 & 1.00 & 0.91 & 0.00 \\
Arts (50) & 0.11 & 0.77 & 0.06 & 0.34 \\
Other & 0.18 & 0.59 & 0.58 & 0.37 \\
\hline
\end{tabular}


C. Share of For-Profit FTE Enrollments in Non-Title IV Institutions, by Program and State

\begin{tabular}{lccc}
\hline Program (CIP codes) & FL & MI & WI \\
\hline Agriculture (01) & 0.59 & 1.00 & 1.00 \\
Business (52) & 0.01 & 0.88 & 0.05 \\
Communications (09, 10) & 0.05 & 0.04 & 0.01 \\
Computer Science (11) & 0.03 & 0.93 & 0.07 \\
Construction (46, 48) & 0.02 & 0.74 & 0.63 \\
Engineering (14, 15) & 0.00 & 0.96 & 0.00 \\
Health (51) & 0.05 & 0.23 & 0.19 \\
Security \& Law Enforcement (43) & 0.00 & 0.11 & 0.00 \\
Mechanics (47) & 0.01 & 0.70 & 0.86 \\
Personal \& Culinary (12) & 0.16 & 0.34 & 0.69 \\
Religion (39) & 0.00 & 1.00 & 0.00 \\
Transportation (49) & 0.55 & 1.00 & 0.00 \\
Arts (50) & 0.02 & 0.48 & 0.82 \\
Other & 0.01 & 0.20 & 0.01 \\
\hline
\end{tabular}

D. Share of For-Profit FTE Completions in Non-Title IV Institutions, by Program and State

\begin{tabular}{lccc}
\hline Program (CIP codes) & FL & MI & WI \\
\hline Agriculture (01) & 0.58 & 1.00 & 1.00 \\
Business (52) & 0.02 & 0.92 & 0.21 \\
Communications (09, 10) & 0.07 & 0.05 & 0.06 \\
Computer Science (11) & 0.13 & 0.97 & 0.22 \\
Construction (46, 48) & 0.05 & 0.95 & 0.95 \\
Engineering (14, 15) & 0.02 & 1.00 & 0.00 \\
Health (51) & 0.17 & 0.33 & 0.31 \\
Security \& Law Enforcement (43) & 0.03 & 1.00 & 0.00 \\
Mechanics (47) & 0.03 & 0.84 & 0.87 \\
Personal \& Culinary (12) & 0.29 & 0.46 & 0.63 \\
Religion (39) & 0.00 & 1.00 & 0.00 \\
Transportation (49) & 0.59 & 1.00 & 0.00 \\
Arts (50) & 0.05 & 0.64 & 0.67 \\
Other & 0.03 & 0.28 & 0.06 \\
\hline
\end{tabular}

Notes: Years vary slightly for each state. See Table 1 for the precise years. Title IV institutions include only non-degree (diploma/certificate) programs.

Sources: State regulatory agencies. See Data Appendix. 


\section{Appendix Table A2. Distribution of Non-Title IV and Title IV Enrollment across Programs, by State}

Program's Share of Enrollment among Title IV and Non-Title IV Institutions, by State (columns sum to 1)

\begin{tabular}{|c|c|c|c|c|c|c|c|c|}
\hline \multirow[b]{2}{*}{ Program (two-digit CIP codes) } & \multicolumn{2}{|c|}{ FL } & \multicolumn{2}{|c|}{ MI } & \multicolumn{2}{|c|}{$\mathrm{TN}$} & \multicolumn{2}{|c|}{ WI } \\
\hline & NT4 & $\mathrm{T} 4$ & NT4 & $\mathrm{T} 4$ & NT4 & $\mathrm{T} 4$ & NT4 & $\mathrm{T} 4$ \\
\hline Agriculture (01) & 0.007 & 0.001 & 0.002 & 0.000 & 0.001 & 0.000 & 0.014 & 0.018 \\
\hline Business (52) & 0.030 & 0.002 & 0.255 & 0.019 & 0.124 & 0.062 & 0.227 & 0.012 \\
\hline Communications $(09,10)$ & 0.010 & 0.000 & 0.002 & 0.030 & 0.002 & 0.025 & 0.001 & 0.001 \\
\hline Computer Science (11) & 0.089 & 0.047 & 0.230 & 0.028 & 0.056 & 0.118 & 0.020 & 0.013 \\
\hline Construction $(46,48)$ & 0.006 & 0.021 & 0.001 & 0.012 & 0.010 & 0.016 & 0.037 & 0.039 \\
\hline Engineering $(14,15)$ & 0.011 & 0.004 & 0.080 & 0.006 & 0.000 & 0.003 & 0.000 & 0.000 \\
\hline Health (51) & 0.389 & 0.532 & 0.169 & 0.513 & 0.244 & 0.363 & 0.301 & 0.590 \\
\hline Security and Law Enforcement (43) & 0.008 & 0.001 & 0.032 & 0.004 & 0.003 & 0.056 & 0.000 & 0.001 \\
\hline Mechanics (47) & 0.015 & 0.114 & 0.027 & 0.021 & 0.007 & 0.105 & 0.042 & 0.049 \\
\hline Personal and Culinary (12) & 0.295 & 0.243 & 0.117 & 0.340 & 0.205 & 0.159 & 0.138 & 0.160 \\
\hline Religion (39) & 0.000 & 0.000 & 0.038 & 0.000 & 0.086 & 0.008 & 0.000 & 0.000 \\
\hline Transportation (49) & 0.119 & 0.012 & 0.005 & 0.000 & 0.214 & 0.011 & 0.000 & 0.045 \\
\hline Arts (50) & 0.009 & 0.003 & 0.011 & 0.012 & 0.002 & 0.040 & 0.053 & 0.045 \\
\hline Other & 0.023 & 0.019 & 0.002 & 0.012 & 0.141 & 0.035 & 0.009 & 0.027 \\
\hline
\end{tabular}

Notes: Years vary somewhat for each state. See Table 1 for the precise years.

Sources: State regulatory agencies. See Data Appendix. 